\title{
Second Generation State Takeover Statutes and Shareholder Wealth: An Empirical Study
}

\author{
Jo Watson Hackl and Rosa Anna Testani†
}

Over the last two decades, government regulation of tender offers ${ }^{1}$ has been a controversial and evolving field. At the center of much of the controversy surrounding regulation of the takeover process remains an uncertainty about the effects of existing statutes governing takeovers. While it is widely accepted that takeover regulation should maximize shareholder wealth, ${ }^{2}$ disagreement over the economic effects of takeovers has led to differing conceptions of how to achieve this goal. ${ }^{3}$ Some commentators argue that regulations that delay the takeover process ${ }^{4}$ benefit shareholders by triggering auctions. Bidding among potential acquirers increases the amount that shareholders of the target firm receive and efficiently allo-

† We are grateful to Professor Roberta Romano for her comments, guidance and support. We are also grateful to ADP Network Services for generously providing us with the Mergers and Acquisitions Journal tender offer database. We also thank the companies involved in our study that responded to our written and telephone inquiries.

1. Tender offers are a method of acquiring a controlling interest in a firm by soliciting the firm's shareholders to tender, or sell, their stock to the offeror for a specified price. This price may be offered in cash, stock, debt, or a combination. For a discussion of the characteristics of tender offers, see Securities and Exch. Comm'n v. Carter Hawley Hale Stores, Inc., 760 F.2d 945, 950-52 (9th Cir. 1985). Two other takeover devices are mergers and proxy contests. This Note focuses only on the regulation of cash tender offers because they are the most effective method of accomplishing a hostile takeover. See Fischel, Efficient Capital Market Theory, the Market for Corporate Control, and the Regulation of Cash Tender Offers, 57 TEx. L. REv. 1, 2 (1978). For a discussion of the unique role of hostile takeovers in the market for corporate control, see infra Section I-B-1.

2. There is no universal definition of shareholder wealth. We used measures of shareholder wealth common to both sides of the debate about takeover regulation: the quantitative returns received by target shareholders, as measured by control premiums and cumulative abnormal returns. See infra text accompanying notes $127-30$.

3. These disagreements stem partially from the various perspectives of different shareholders. Arguments based on the "fairness" of takeovers generally approach regulation from the perspective of shareholders of the acquired, or target, firm. Shareholder wealth is maximized if the ex post result of the tender offer regulation is an increase in the control premiums and the returns to target shareholders. See, e.g., Brudney \& Chirelstein, Fair Shares in Corporate Mergers and Takeovers, 88 HaRv. L. Rev. 297 (1974). Arguments from the perspective of shareholders generally are based on efficiency grounds and focus on the economic effects of takeovers and takeover regulation on the product, capital, and managerial markets. See infra notes 25-27 and accompanying text. Thus, shareholder wealth is maximized if the ex ante effects of the regulation increases efficiency in these markets so as to benefit all shareholders.

4. This Note studies the effects of the "second generation" of state statutes regulating tender offer. These statutes generally introduce delays in the takeover process. See infra Section II. For a discussion of first generation statutes, see infra notes 15-17 and accompanying text. 
cates resources. ${ }^{5}$ Other commentators argue that minimal regulation of takeovers maximizes shareholder wealth because delay discourages takeovers and thereby impedes a fluid market for corporate control. ${ }^{6}$ Takeovers improve market efficiency which benefits all shareholders. ${ }^{7}$ Thus, less regulation would result in more takeovers and shareholders as a group would be better off.

This Note advances the theoretical debate by resolving some of the uncertainty about the effects of the "second generation" of state statutes that regulate takeovers. ${ }^{8}$ Our study is the first to examine the direct effects ${ }^{8}$ of these statutes on cash tender offers. ${ }^{10}$ We compare the effect on shareholder wealth of the three types of second generation statutes: control share acquisition, fair price, and shareholder demand statutes. ${ }^{11}$ The Note

5. See infra notes $35-37$ and accompanying text.

6. See infra notes $38-40$ and accompanying text. For a discussion of the market for corporate control, see infra section I-B-1.

7. See infra notes $21-24$ and accompanying text.

8. During the period of our study, 1981-86, nineteen states adopted second generation statutes. The arguments advanced thus far in the debate about whether the second generation of state regulations actually deter takeover attempts have been based on logic and intuition, rather than empirical data. The lack of empirical studies in this area may have worked to the detriment of Dynamics Corporation in CTS Corp. v. Dynamics Corp. of America, 107 S. Ct. 1637 (1987) (upholding Indiana second generation takeover statute against commerce and supremacy clause challenges). As the Supreme Court noted, "Dynamics' argument that the [Indiana Control Share Acquisition] Act is unconstitutional ultimately rests on its contention that the Act will limit the number of successful tender offers. There is little evidence that this will occur." Id. at 1652. The Court failed to observe, however, that there is little evidence that tender offers would not be deterred. Instead, the Court held that "even if the Act should decrease the number of successful tender offers for Indiana corporations, this would not offend the Commerce Clause." Id.

9. Second generation statutes apply only to firms incorporated by the regulating state. This limited territorial application enables a more precise measurement of the effect of these statutes. $C f$. infra note 98 (criticizing study of first generation statutes). Our Note does not examine the full extent of the effects of the second generation statutes since only transactions initiated by tender offers were studied. See infra notes $57,68, \& 87$.

10. Three event studies have examined the market's reaction to the enactment of particular second generation statutes on all firms potentially subject to the regulation, but did not study their actual effects. See infra notes $115-119$ and accompanying text.

11. Second generation statutes have been classified into these categories according to their terms. See Romano, The Political Economy of Takeover Statutes, 73 VA. L. REv. 111, 115-17 (1987). For a detailed discussion of these statutes, see infra text accompanying notes 56-94. Second generation statutes substantively regulate the tender offer process either by requiring majority shareholder approval before voting control can be acquired, (control share acquisition statutes), see infra text accompanying notes 56-67; by requiring supermajority approval by the disinterested shareholders or the target's board for a merger with an "interested shareholder" unless the remaining target shareholders receive at least the tender offer price, (fair price statutes), see infra text accompanying notes 68-85; or by giving target shareholders who did not tender the right to demand cash for their shares (shareholder demand statutes), see infra text accompanying notes 86-94. The shareholder demand statutes have often been called "redemption rights" statutes in the academic literature. We use the term "shareholder demand" because this type of statute gives target shareholders the right to demand cash for their shares from the acquirer rather than from the target, as implied by the term "redemption."

This Note will not attempt to examine the effects of "third generation" disclosure statutes. These statutes were passed too recently to include takeovers subject to them in our study. See Hersch \& Kearney, State Takeover Laws: The Third Generation, in Practising Law Institute, Series No. 543, 18th Annual Institute on Securities Regulation 450-60 (1986) [hereinafter PractisING LAw InstrTUte]. Five states, Kentucky, Missouri, Indiana, New Jersey, and New York, have recently passed stronger versions of the fair price statute. These statutes are characterized by a moratorium for five years after becoming an interested shareholder, with limited exceptions, on business 
also examines competing hypotheses of takeover regulation against our evidence of the effects of these statutes on the number of firms that were targets of tender offers, the percentage of targets successfully acquired in transactions initiated by tender offers, the number of multiple tender offers for the same firm, the control premiums paid to target shareholders in the tender offer, and the market's subsequent valuation of the target.

Our study found that the statutes had a negative effect on shareholder wealth. After adjustment for the number of public firms incorporated in each state, the number of takeover attempts in states with second generation regulation decreased relative to the number of takeover attempts in states without second generation regulation. There was no difference in the amount tendering shareholders received when the second generation statutes applied. Thus, shareholder wealth was not maximized under the ex post view because the statutes did not increase the control premiums paid to target shareholders and did not increase the market returns earned on the stock of the target firm after takeover. The statutes decreased shareholder wealth under the ex ante view by deterring takeovers and thereby impeding the efficiency of the market for corporate control.

Section I of this Note places the second generation statutes in historical context and summarizes the theoretical debate concerning the role of takeovers in promoting market efficiency and the effects of takeover regulation. Section II discusses the terms of the statutes and how they might be expected to affect takeovers. Section III reviews the empirical literature concerning the effects on the takeover process of federal regulation, state regulation, and management defensive tactics. Section IV presents our methodology and results. Finally, Section V discusses the implications of our study for theories of takeover regulation.

\section{Federal and State Regulation of Tender Offers}

Second generation statutes can best be understood as one developmental stage in the states' efforts to regulate tender offers. Before we discuss the specific terms of the second generation statutes, it is necessary to place the statutes within the context of these efforts. This section briefly discusses federal and state regulation of tender offers and summarizes the frame-

combinations. IND. Code ANN. § 23-1-43-18 (Burns 1987) (effective Apr. 1, 1987); Ky. REv. STAT. ANN. § 271A.397(3) (Baldwin Supp. 1987) (effective Mar. 28, 1986); Mo. ANN. STat. § 351.459(2) (Vernon 1986) (effective June 23, 1986); N.J. STAT. ANN. § 14A: 10A-1-6 (West Supp. 1987) (effective Jan. 23, 1986); N.Y. Bus. CorP. LAw $\$ 912$ (McKinney 1986) (effective Dec. 16, 1985). See also Del. Code ANN. tit. 8, $\S 203$ (Supp. 1988) (effective Dec. 23, 1987) (three-year freeze); 1987 Wis. Act 45 (to be codified at WIs. STat. ANN. $\$ 180.726$ ) (effective Sept. 10, 1987) (three-year freeze). Both the Delaware and New York laws were constitutionally challenged. See Black \& Decker Corp v. American Standard, Inc., 679 F. Supp. 1183 (D. Del. 1988) (denying request for preliminary injunction against Delaware statute); Salant Acquisition Corp. v. Manhattan Indus., Inc., 682 F. Supp. 199 (S.D.N.Y. 1988) (denying request for preliminary injunction against New York statute). 
work of the debate about whether such efforts benefit or harm shareholders.

\section{A. Federal Regulation and the First Generation State Statutes}

In 1968 the Williams Act first subjected cash tender offers to federal regulation. ${ }^{12}$ The enactment of this statute was prompted in large part by concern about the coercive pressure ${ }^{13}$ on target shareholders to tender their shares. By mandating disclosure by the bidder and requiring that tendered shares be accepted pro rata, the Act provided target shareholders with time and information on which to base their decision to tender. ${ }^{\mathbf{1 4}}$

The adoption of this Act did not end dissatisfaction with some aspects of tender offers. Twenty-seven states enacted statutes that introduced delays in the takeover process beyond those mandated by the Williams Act. ${ }^{15}$ Since these "first generation" statutes applied to corporations doing business in the state, incorporated by the state, or with a certain percentage of shareholders in the state, a takeover could be subject to conflicting regulation by more than one state. The Supreme Court struck down the Illinois Act in 1982 as an unconstitutional burden on interstate commerce. ${ }^{16}$ The remaining first generation statutes ${ }^{17}$ were either repealed, not enforced,

12. The Williams Act, Pub. L. No. 90-439, 82 Stat. 454 (July 29, 1968) (codified as amended at 15 U.S.C. $\$ \S 78 \mathrm{~m}$ (d)-(e), $78 \mathrm{n}(\mathrm{d})-(\mathrm{f})(1982))$.

13. See infra note 19 .

14. Persons must file an information statement, Schedule 14D-1, with the Securities Exchange Commission (SEC) and send it to the target within 10 days of acquiring direct or beneficial ownership of $5 \%$ or more of a class of stock. 17 C.F.R. $\$ 240.14 d-3$ (1987).

Shareholders who tender may withdraw their shares until seven business days after notice of the tender offer was given or if 60 business days after the making of the tender offer have passed. 15 U.S.C. $\$ 78 \mathrm{n}$ (d)(5) (1982). The SEC extended the right to withdraw for the duration of the tender offer. 17 C.F.R. $\S 240.14 d-7$ (a) (1987). Shareholders who tender early receive the benefit of any subsequent increase in the tender offer price. 15 U.S.C. $\$ 78 \mathrm{n}(\mathrm{d})(7)(1982)$. When a tender offer is oversubscribed, the shares must be purchased pro rata according to the number of shares tendered by each shareholder. $I d$. $\$ 78 \mathrm{n}(\mathrm{d})(6)$.

15. These are the "first generation" statutes. The Illinois Takeover Act, IlL. Rev. STAT. ch. 121 $1 / 2$ IT 137.51-.70 (1981) (repealed), was a typical first generation statute. The Illinois Act required potential tender offers to be registered with the Secretary of State if $10 \%$ or more of the target firm was owned by Illinois shareholders or if two of the following conditions were met: the principal executive office of the target was located in Illinois, the target was incorporated in Illinois, or at least $10 \%$ of the target's paid-in capital was represented in Illinois. Id. $\$ 137.52-10$. The Secretary had 20 business days in which to call a hearing and adjudicate the fairness of the offer. Id. II 137.54.E The Secretary could prevent the tender offer if the registration statement did not provide full and fair disclosure of all material information, if the terms of the takeover were inequitable, or if the terms would be fraudulent to the shareholders. Id. If 137.57.

16. Edgar v. MITE Corp., 457 U.S. 624 (1982). The plurality opinion held that the burden placed on interstate commerce by the extraterritorial reach of the statute outweighed Illinois's local interest in regulating takeovers. Three concurring justices, Burger, Blackmun and White, went further and declared that the Williams Act preempted the Illinois statute. Id. at 639-40 (White, J., concurring). They found that the 20 -day waiting and hearing requirements imposed delays that favored incumbent management, upsetting the careful balance struck by Congress in the Williams Act between the interests of acquirers and management. Id. at 639. However, since the MITE majority did not reach the preemption issue, states were free to adopt new statutes regulating takeovers.

17. For a list of first generation statutes, see Warren, Developments in State Takeover Regulation: MITE and Its Aftermath, 40 Bus. LAw. 671, 671 n.3 (1983). 
modified to conform to the Williams Act, or did not survive constitutional challenge. ${ }^{18}$ State efforts to regulate takeovers continued. Citing continuing concern about fairness to target shareholders, ${ }^{19}$ many states enacted "second generation" statutes.

\section{B. The Theoretical Debate Surrounding Takeover Regulations}

State regulation of takeovers is significant in corporate law because takeovers promote market efficiency. This part first discusses the role of takeovers and then summarizes the debate over the deterrent effect of regulation that delays the takeover process.

\section{Takeovers in the Market for Corporate Control}

The corporate form provides firm managers with significant discretion as to the use of firm assets. ${ }^{20}$ Tender offers are used to replace management who use their discretion in a way that does not maximize the target's value. ${ }^{21}$ Potential acquirers, perceiving this suboptimal management

18. See, eg., Telvest, Inc. v. Bradshaw, 697 F.2d 576 (4th Cir. 1983); Martin-Marietta Corp. v. Bendix Corp., 690 F.2d 558 (6th Cir. 1982); Bendix Corp. v. Martin Marietta Corp., 547 F. Supp. 522 (D. Md. 1982); Esmark, Inc. v. Strode, 639 S.W.2d 768 (Ky. 1982) (each striking down state statute as unconstitutional burden on interstate commerce).

19. One concern motivating second generation statutes was the coercive nature of two-tier offers. A two-tier offer consists of a partial offer for control (first tier) followed by a merger (second tier). In partial tender offers, the bidder acquires a controlling bloc of voting shares and then proposes a merger. Office of the Chief Economist of the Securities and Exch. Comm'n, The Economics of Anyor-All, Partial and Two-Tier Tender Offers 6 (Apr. 1, 1985) (on file with the Yale Law Journal) [hereinafter OCE, Any-or-All]. In the "second-step freezeout" the target is merged into the acquirer and the minority (nontendering) shareholders are forced to accept a price below the first tender offer price. The consideration in this step is often paid in securities of the new corporation rather than cash. Id. at 8 . This package of securities may be worth less than the price paid to shareholders who tendered in the first step. Some commentators argue that the possibility of being frozen out unfairly coerces shareholders into tendering their shares whether or not they feel that the potential takeover is best for the firm. This creates a type of "prisoners' dilemma" in which target shareholders tender for fear of being frozen out later. See, e.g., Bradley, Interfirm Tender Offers and the Market for Corporate Control, 53 J. Bus. 345, 356 (1980); Two types of second generation statutes respond to this criticism-the fair price and the shareholder demand statutes. A recent study by the SEC, however, found little distinction between the coercive nature of two-tier bids and the general coercive pressure involved in the tender offer decision. OCE, Any-or-All, supra, at 26. During 1981-84, the average control premium paid in any-or-all offers, $59.6 \%$, was similar to the average blended premium paid in two-tier offers, $54.5 \%$. A blended premium is the sum of the control premiums paid to the shareholders in each tier, weighted by the proportion of shares receiving the premium over the total shares tendered. Id. at 3 . As a result, the SEC concluded that no prohibition against two-tier tender offers is necessary. Id. at 26.

20. The separation of ownership and control in the corporate form creates agency costs, the sum of the costs arising from the monitoring of management's performance by shareholders, expenditures by managers to convince shareholders that they will not shirk (bonding costs), and residual losses caused by managerial self-dealing. See Alchian \& Demsetz, Production, Information Costs, and Economic Organization, 62 AM. EcoN. Rev. 777, 781-83, 787-94 (1972); Jensen \& Meckling, Theory of the Firm: Managerial Behavior, Agency Costs and Ownership Structure, 3 J. FIN. EcoN. 305, 308-10 (1976). For a discussion of agency costs in the corporate form, see generally Brudney, Corporate Governance, Agency Costs, and the Rhetoric of Contract, 85 CoLuM. L. REv. 1403 (1985).

21. Tender offers are a check on management's discretion because they may change control of the firm despite the opposition of target management. See Fischel, supra note 1, at 2 (tender offer most effective means of replacing entrenched management). 
of resources, may attempt takeovers for a variety of reasons: a potential acquirer may anticipate either synergistic gains, including economies of scale, ${ }^{22}$ or monopolistic gains from a merger with the target; the acquirer's management may nevertheless think that the target is a good long-term investment; the acquirer may feel that the firm is a "bargain purchase",23 or, most important, the acquirer may seek a gain by taking over the firm and managing its assets more efficiently. ${ }^{24}$

The threat of takeovers monitors management's performance and increases the firm's market value generally by reducing the agency costs created by management diversion of assets. ${ }^{25}$ The incumbent management

22. For a discussion of the synergistic gains resulting from mergers, see Lintner, Expectations, Mergers and Equilibrium in Purely Competitive Securities Markets, 61 AM. ECON. REv. 101, 106-10 (May 1971) (Papers and Proceedings). For empirical support, see Bradley, Desai \& Kim, The Rationale Behind Interfirm Tender Offers: Information or Synergy?, 11 J. FIN. EcoN. 183, 194-95 (1983) (concluding that gains produced in tender offers are created by synergy, not the bidder's communication that target is undervalued, since stock price gains from announcement of unsuccessful tender offers dissipate if target not successfully acquired within five years).

Synergy may come from financial efficiencies as well as financial economies such as tax savings. The latter is the only gain from economic activity that does not increase social wealth. Leebron, Games Corporations Play: A Theory of Tender Offers, 61 N.Y.U. L. REv. 153, 209 (1986). However, this type of gain is not a factor in many transactions. Id. at 204.

23. A target is a bargain purchase if the bidder has better information regarding the potential value of the target than the target's management or the market. See V. BRudNEY \& M. CHIRELstein, Corporate Finance: Cases and Materials 506-07 (2d ed. 1979) (excerpting Federal Trade Commission merger report). Gains accrue to target shareholders even if the tender offer is unsuccessful because new information is communicated to the market about the target's true value. Professor Bebchuk notes, however, that this does not affect the value of the target; instead, a tender offer "merely accelerates an adjustment in the market price that would ultimately occur anyway." Bebchuk, The Case for Facilitating Competing Tender Offers, 95 Harv. L. REv. 1028, 1033 (1982). See also Dodd \& Ruback, Tender Offers and Stockholder Returns: An Empirical Analysis, $5 \mathrm{~J}$. FIN. ECoN. 351 (1977) (concluding that best explanation for target gains is informational rather than synergistic or monopolistic theories). But see Jarrell, Brickley \& Netter, The Market for Corporate Control: The Empirical Evidence Since 1980, 2 J. Econ. PersP. 49, 55-56 (1988) (recent empirical evidence indicating target firms not undervalued by market since targets return to prebid levels after unsuccessful takeover attempts despite information disclosed during takeover contests).

24. If the target's stock is valued low in the market because it is poorly managed, an acquirer can profit by taking over the firm at the low market price plus a control premium and managing the corporate assets more efficiently. The stock price of the target will then rise to capitalize the improved earnings performance. This increase in the stock price of the target is predicted by the Efficient Capital Market Theory. For a more detailed discussion of the Efficient Capital Market Theory and the empirical evidence supporting the strong, semi-strong, and weak versions of this theory, see Fama, Efficient Capital Markets: A Review of Theory and Empirical Work, 25 J. Fin. 383 (1970). For a discussion of this theory in the takeover process, see Easterbrook \& Fischel, The Proper Role of a Target's Management in Responding to a Tender Offer, 94 HARv. L. REv. 1161, 1165-68 (1981) [hereinafter Easterbrook \& Fischel, The Proper Role].

When a firm is poorly managed, "the market price of the shares declines relative to the shares of other companies in the same industry." Manne, Mergers and the Market for Corporate Control, 73 J. Pol. ECON. 110, 112 (1965). This prediction is consistent with evidence cited by Easterbrook and Fischel that after adjusting for market changes, the price of a target's stock declines for some 40 months preceding a tender offer. Easterbrook \& Fischel, Takeover Bids, Defensive Tactics, and Shareholders' Welfare, 36 Bus. LAw. 1733, 1739 (1981). The lower the price of the target's stock relative to the potential returns to shareholders under a more effective management, the more attractive a target is for takeover. Manne, supra, at 113.

For a general evaluation of several explanations for takeovers, see Coffee, Regulating the Market for Corporate Control: A Critical Assessment of the Tender Offer's Role in Corporate Governance 84 Colum. L. Rev. 1145, 1163-75 (1984).

25. See Easterbrook \& Fischel, The Proper Role, supra note 24, at 1169-74; see also H.R. REP. 
of potential targets are exempt from the threat of takeover to the extent that information costs, prevailing federal and state statutory constraints, and other factors increase the costs of takeovers or otherwise limit the ability of others to cause a change in control of the target. This amount of immunity from pressure in the market for corporate control ${ }^{26}$ allows management to appropriate the firm's assets for its own benefit without fear of being replaced by shareholders. The threat of a takeover reduces management's ability to self-deal or to operate inefficiently and decreases agency costs by aligning management's interests with those of shareholders. The reduction of agency costs through takeovers leads to generally higher stock values by allocating these resources to more productive activities. Shareholders of the target who tender benefit from the premium that they receive for their shares. ${ }^{27}$ Moreover, shareholders in general benefit from the increased efficiency in the market for corporate control and in the operation of the firms that takeovers accomplish.

\section{The Debate Surrounding the Effects of Delay on the Frequency of Takeovers}

While promoting market efficiency benefits shareholders generally, takeovers may coerce and pressure individual shareholders to tender their shares. Federal and state regulation responded to this criticism of tender offers by providing target shareholders with more time to consider a tender offer. This time requirement may also benefit target management.

No. 1373, 94th Cong., 2d Sess. 12 (1976) ("Thus, the very possibility of a successful cash tender offer may exert a pro-competitive influence in the marketplace by keeping incumbent management 'on their toes,' and by forcing them to keep their firm efficient and successful.").

The threat of a takeover is not the only check on management's discretion. Managerial performance is also monitored by competition in the capital markets, the product markets, and the market for managerial talent. See Gilson, A Structural Approach to Corporations: The Case Against Defensive Tactics in Tender Offers, 33 STAN. L. Rev. 819, 836-40 (1981). See also Easterbrook, Managers' Discretion and Investors' Welfare: Theories and Evidence 9 DEL. J. CoRP. L. 540 (1984). Moreover, when targets have substantial cash flows that are being reinvested at a lower rate of return by management than could be earned by the shareholders if the cash were distributed to them, a highlyleveraged takeover can reduce agency costs. The debt incurred to finance the takeover performs a monitoring function. Additionally, paying target shareholders a high control premium reduces agency costs by eliminating the pool of cash available for management self-dealing. See Jensen, Agency Costs of Free Cash Flow, Corporate Finance, and Takeovers, 76 AM. EcoN. Rev. 323, 324-26 (1986) (Papers \& Proceedings).

26. For an extensive review of the empirical evidence examining the market for corporate control, see Jensen \& Ruback, The Market for Corporate Control: The Scientific Evidence, 11 J. FIN. Econ. 5 (1983); Jarrell, Brickley \& Netter, supra note 23. See also Ruback, Assessing Competition in the Market for Corporate Acquisitions, $11 \mathrm{~J}$. FIN. ECoN. 141 (1983) (empirical finding supporting existence of competitive acquisitions market that alleviates separation of ownership and control problems, efficiently allocates resources, and eliminates need for state and federal securities regulation).

27. "The source of the premium is the reduction in agency costs, which makes the firm's assets worth more in the hands of the acquirer than they were worth in the hands of the firm's managers." Easterbrook \& Fischel, The Proper Role, supra note 24, at 1173. But see Speech by Harold Williams, Former Chairman, SEC, before Seventh Annual Security Regulation Institute Jan. 17, 1980, repri ted in [1979-80 Transfer Binder] FED. SEC. L. REP. (CCH) I 82,445 (recent takeovers due more to undervalued stock and ambitious raiders than to synergistic or efficiency gains; takeovers divert resources that could be used for more productive uses such as capital reinvestment). 
Regulatory delay ${ }^{28}$ gives incumbent management time to formulate a strategy to resist a takeover, ${ }^{29}$ such as initiating litigation against the offeror, ${ }^{30}$ searching for a "white knight," engaging in a recapitalization, adopting poison pill plans or making a competing self-tender offer. Additionally, the Williams Act and second generation statutes mandate disclosure of some of the initial tender offeror's information and intentions concerning the target. ${ }^{31}$ This allows later bidders to gain the benefit of the first bidder's research of the target, or the "sunk costs" that the first bidder has invested. ${ }^{32}$ This may lead to a bidding war, or an auction, among potential acquirers. ${ }^{33}$ Commentators predict that the delay required by state statutes will facilitate an increase in auctions among bidders and thus increase the control premium offered to target shareholders. ${ }^{34}$

Academic commentators sharply disagree over whether regulation that increases the control premiums paid to target shareholders is desirable. One view is that increasing control premiums makes the market more efficient because it allocates the resources of each target to the party who values them the highest. ${ }^{35}$ The bidder who values the assets most highly is necessarily the one who anticipates the most efficient use of them. Target shareholders will gain from the higher control premium. ${ }^{36}$ General shareholder wealth will be increased because this mechanism allocates scarce resources to their most productive uses with fewer transaction costs than a non-auction process that relies on the acquirer to later resell the target assets to their most efficient user. ${ }^{37}$

Some commentators argue that increasing delay in the takeover process

28. The Williams Act and the rules promulgated by the SEC provide that tender offers must remain open for at least 20 business days. 17 C.F.R. $\S 240.14 \mathrm{e}-1$ (1987). The provisions for shareholder approval in second generation statutes also impose delays on the takeover process. See infra Section II.

29. See Gogelson, Mergers and Acquisitions: Developments on Defense, reprinted in Practising LAW INSTITUTE, supra note 11, at 353 (discussing various defensive maneuvers used by target management to defeat tender offers).

30. A recent study suggests that litigation may be the most effective defensive tactic. Rosenzweig, Target Litigation, 85 MICH. L. REv. 110, 127-28 (1986).

31. See supra note 14.

32. A second bidder may then make a slightly higher tender offer. See Easterbrook \& Fischel, Auctions and Sunk Costs in Tender Offers, 35 Stan. L. Rev. 1, 2 (1985).

33. See Easterbrook \& Fischel, The Proper Role, supra note 24, at 1178-79.

34. See, e.g., Bebchuk, The Case for Facilitating Competing Tender Offers: A Reply and Extension, 35 Stan. L. Rev. 23, 24 (1982).

35. Bebchuk, supra note 23, at 1048; see Gilson, supra note 25, at 872; Gilson, Seeking Competitive Bids Versus Pure Passivity in Tender Offer Defenise, 35 Stan. L. Rev. 51, 62-64 (1982).

36. Professor Bebchuk notes that an auction-promoting rule prevents takeovers from occurring at low control premiums. Therefore, he argues, it allows target shareholders to receive a substantial share of the social gains generated by takeovers. Bebchuk, supra note 23, at 1040-41. However, Professors Easterbrook and Fischel note that increased control premiums received by target shareholders "are exactly offset by the bidder's payment and thus by a loss to the bidder's shareholders. Shareholders as a group gain nothing ...." Easterbrook \& Fischel, The Proper Role, supra note 24, at 1175. They also suggest that higher control premiums are a result of a pre-bid market price for each target that is lower than it would be if the takeovers were not impeded by statutory delay. See Easterbrook \& Fischel, supra note 32, at 7 n.16.

37. See Bebchuk, supra note 34, at 39-42; Gilson, supra note 35, at 62-64. 
decreases the likelihood of takeovers in two ways. Although delay may promote auctions, it discourages the first bidder from incurring the substantial costs involved in identifying a takeover target and making a tender offer. ${ }^{38}$ Suboptimal searching activity would result in a decrease in the number of takeovers.

Second, an increase in the control premiums increases the total costs of taking over a firm because the successful acquirer must pay more for each target share. The higher cost of each takeover thus deters takeovers at the margin. ${ }^{3 \theta}$ Monitoring costs increase and shareholder wealth decreases because only the most poorly performing firms can be profitably acquired. Individually, target shareholders do benefit in specific instances from an auction because they each receive a higher price for their shares. But from an ex ante perspective, shareholders prefer more value-producing transactions because they are diversified and own both stock of acquirers and targets. ${ }^{10}$ Lower control premiums are beneficial if they result in more takeovers. ${ }^{41}$ Therefore, these commentators argue that shareholder wealth will be increased by a rule which decreases the costs of takeovers, thereby making the valuation of firms and the market for corporate control more efficient. $^{42}$

Other commentators argue that rules which impose delay ${ }^{43}$ do not sig-

38. Proponents of this view note that first bidders incur significant searching costs, including time spent by the management of the potential acquirer in evaluating the target and maintaining access to large amounts of capital. They predict that "free riding," made possible by mandatory disclosure, decreases the incentives for the first bidder to incur these searching costs. Under this view the ability of the initial bidder to recover searching costs through the sale of a bloc of stock at a premium if another bidder acquires the target is not sufficient incentive for a potential bidder to incur substantial searching costs. See Easterbrook \& Fischel, supra note 32, at 5-7.

39. The effect of increasing the control premium on the frequency of takeovers is critical in determining whether shareholder wealth is maximized. Both sides of the debate agree that shareholder wealth is maximized by increasing the expected takeover premium (the probability of a successful tender offer multiplied by the control premium paid). Bebchuk, supra note 23, at 1034; Easterbrook \& Fischel, The Proper Role, supra note 24, at 1164, 1178 n.4. Traditional demand theory is applied to this debate by Coffee, supra note 24 . If the demand for corporate control were elastic as Easterbrook and Fischel assume, then auction rules that increase the cost (premium), would decrease the number of takeovers and shareholders in general would suffer. On the other hand, if the demand for corporate control were inelastic, then increasing the control premium would not affect the frequency of takeovers and shareholder wealth would be maximized under a rule that promotes auctions. The debate may never be definitively resolved. Professor Coffee concludes that "[a]lthough there is evidence that fewer offers have been made as premiums have increased, we lack reliable data by which to estimate the elasticity of the demand curve for corporate control." Id. at 1180.

40. See Easterbrook \& Fischel, supra note 32, at 8-9. Even nondiversified shareholders gain by reducing delays and agency costs since these shareholders do not know beforehand whether their firm is a target or a bidder. Id. at 9.

41. See Easterbrook \& Fischel, The Proper Role, supra note 24, at 1179.

42. Id. at $1175-80$.

43. Professor Bebchuk, the principal proponent of this view, does not advocate the current second generation statutes. Provisions that assure that the same price is paid in a two-tier acquisition, such as the fair price and shareholder demand statutes, distort shareholder decisions by systematically biasing shareholders not to tender since the second-step freezeout may not occur. This relates back to the prisoners' dilemma where shareholders acting individually will cause the bid to fail and thus no one receives the control premiums. See Bebchuk, Toward Undistorted Choice and Equal Treatment in Corporate Takeovers, 98 HARv. L. REv. 1693, 1735-44, (1985). Professor Bebchuk proposed a regulatory scheme for value-maximizing takeovers that deals with the distorted choice and unequal treat- 
nificantly decrease the number of takeovers. ${ }^{44}$ They note that the bidder who first expends time and money to acquire information about the target may recoup some of this investment by buying shares of the target before announcing the tender offer and then selling at a premium if the bid is unsuccessful..$^{45}$ This possibility means that incentives to search for targets will not significantly decrease because of a rule promoting auctions. ${ }^{46}$ Additionally, the possibility of extracting a higher control premium provides target management with an incentive to search for an appropriate acquirer. ${ }^{47}$ Therefore, the number of management-initiated takeovers could increase. ${ }^{48}$

\section{Second Generation State Takeover Statutes}

This section examines the second generation statutes, compares the three types of second generation statutes, and discusses the way each may be expected to promote delay in the takeover process. Second generation takeover statutes were in effect in nineteen states during the period of our study. ${ }^{49}$ The three representative types of takeover statutes are Indiana's "control share acquisition,"50 Maryland's "fair price," and Pennsylvania's

ment problems faced by target shareholders. Id. at 1747-64. It is basically a control share acquisition scheme.

44. See Bebchuk, supra note 23, at 1037-38 ("[B]ecause current search activity is substantial, it is far from clear that a given increase in the incentives for search [by eliminating rules that promote auctions] will substantially increase the number of identified targets.").

45. Since the prospective bidder may acquire up to $5 \%$ of the firm's stock in open market purchases before making any disclosures, see supra note 14, a gain will be realized on the pre-offer purchase whether or not the original bidder's tender offer is successful, "a profit that might well reach two to four percent of the target's value." Bebchuk, supra note 34, at 31; Gilson, supra note 35, at $52-62$.

46. While Professor Bebchuk acknowledges that a rule which does not promote auctions would encourage searching activity, the increased expenditures would not necessarily result in more beneficial acquisitions. Bebchuk posits that the market may already be near or at an optimal level of search. Thus the marginal benefits of increasing search for targets by bidders do not substantially exceed the marginal social costs. Bebchuk, supra note 34 , at 33 . Auction rules only discourage "foreknowledgemotivated" takeovers, those takeovers in which the acquirer's gain is a result of nonpublic information that the target is undervalued by the market. In foreknowledge-motivated takeovers, the social gain of accelerating the market adjustment of the target is less than the private gains to the searcher. Bebchuk, The Case for Facilitating Competing Tender Offers: A Last (?) Reply, 2 J.L. Econ. \& Org. 253, 257 (1986). See Lowenstein, Pruning Deadwood in Hostile Takeovers: A Proposal for Legislation, 83 Colum L. REv. 249, 322-25 (1983) (proposing legislation with six-month tender offer period to encourage competitive auctions and discourage ill-conceived bids). But see Schwartz, Search Theory and the Tender Offer Auction, 2 J.L. EcoN. \& ORG. 229, 238 (1986) ("The probability that a nonmaximizing firm will be discovered varies directly with the amount of search for such firms. Since the amount of search itself varies directly with the net expected gain to search, lowering this gain ... must also reduce the probability. Auction proponents thus err in claiming that auctions have no adverse effect on search.").

47. Bebchuck, supra note 34 , at 38 .

48. Id. at 38-39.

49. Most of the statutes have been amended and many states enacted statutes regulating takeovers after the period of our study. See e.g., Pamepinto \& Heard, New State Regulation of Corporate Takeovers, The Nat. L. J., Sept. 21, 1987, at 26, col. 1. This discussion focuses only on the provisions in effect during the period of our study, 1981-86.

50. Ohio was the first state to enact a control share acquisition statute. The Indiana statute is the model for our discussion because of its notoriety after the CTS decision. See infra note 55 and accom- 
"shareholder demand" statutes. These statutes codify the more popular forms of charter amendments adopted by firms to fend off hostile takeovers. They differ from their predecessors ${ }^{51}$ in that jurisdiction is confined to takeovers of "domestic" firms, those incorporated by the regulating state. ${ }^{52}$ Moreover, second generation statutes allow firms to "opt out," or exempt themselves from the statutes' requirements. ${ }^{.3}$

During the period of our study, the control share acquisition statutes of several states were constitutionally challenged. ${ }^{54}$ In 1987, the Supreme Gourt upheld the Indiana control share acquisition statute in CTS Corporation v. Dynamics Corporation of America. ${ }^{\mathrm{s}}$

Overall, second generation statutes can be expected to increase the costs of taking over a firm. First, the provisions for shareholder approval introduce delay in the takeover process. This delay may facilitate auctions, resulting in increased control premiums. Second, the provisions for shareholder approval in all three types of statutes may cause control premiums to increase because the potential acquirers are pressured to offer higher control premiums to gain shareholder approval. The distinctive characteristics of each of the three types of statutes are set forth below.

panying text.

51. Some of the second generation statutes contain pre-announcement disclosure requirements. For a discussion of the current constitutional status and jurisdictional bases of these first generation provisions, see Bloomenthal, State Takeover Disclosure Statutes, 9 SEC. \& FED. CoRP. L. REP. 73 (1987).

52. See Note, Edgar v. MITE Corp.: The Death Knell for the Indiana Takeover Offers Act, 16 IND. L. REv. 517 (1983) (evaluating terms of first generation statutes in light of MITE).

53. Generally a company may opt out by amending its charter or bylaws or by a board resolution to the effect that the corporation elects not to be governed by the relevant state statute.

54. The Hawaii, Indiana, Minnesota, Missouri, and Ohio statutes were declared unconstitutional by lower courts. See Terry v. Yamashita, 643 F. Supp 161 (D. Haw. 1986); Dynamics Corp. of America v. CTS Corp., 794 F.2d 250 (7th Cir. 1986), rev'd 107 S. Ct 1637 (1987); APL Ltd. Partnership v. Van Dusen Air, Inc, 622 F. Supp. 1216 (D. Minn. 1985) (earlier version requiring preannouncement disclosures); Gelco Corp. v. Coniston Partners, 652 F. Supp. 829 (D. Minn. 1986), aff'd in part and vacated in part, 811 F.2d 414 (8th Cir. 1987) (constitutional issues moot because bidder revoked tender offer and refused to proceed with another unless court granted original injunctive request); Icahn v. Blunt, 612 F. Supp. 1400 (W.D. Mo. 1985); Fleet Aerospace Corp. v. Holderman, 796 F.2d 135 (6th Cir. 1986), vacated sub nom. Ohio v. Fleet Aerospace Corp., 107 S. Ct. 1949 (1987). These challenges may have had some effect on the number of takeovers under second generation statutes because potential acquirers may have expected the statutes to be declared unconstitutional.

55. $107 \mathrm{~S}$. Ct. 1637 (1987). In a decision that surprised many, the Court reversed the Seventh Circuit Court of Appeals and held that Indiana's control share statute was not preempted by the Williams Act or violative of the commerce clause. The Court stated that the statute "furthers a basic purpose of the Williams Act" by protecting shareholders "from the coercive aspects of some tender offers." Id. at 1645-46. The Indiana statute was not preempted by the Williams Act because it is possible for corporations to comply with both and because the Indiana statute is consistent with the purposes of the Williams Act. Id. at 1644. The Court distinguished the Indiana statute from first generation statutes. Unlike the Illinois statute struck down in Edgar v. MITE Corp., 457 U.S. 624 (1982), Indiana's statute does not favor management, but "protects the independent shareholder against both of the contending parties," namely management and the offeror. CTS, $107 \mathrm{~S}$. Ct. at 1645 . Further, the Court held that the commerce clause was not violated because the statute has the same effect on all offerors for Indiana targets, therefore there was no discrimination against foreign bidders. Id. at 1648-49.

After the CTS decision, the Ohio control share acquisition statute was upheld. Veere, Inc. v. Firestone Tire \& Rubber Co., 685 F. Supp. 1027 (N.D. Ohio 1988). 


\section{A. Control Share Acquisition Statutes}

The Indiana statute requires majority shareholder approval before any person may exercise the voting rights of control shares. ${ }^{58}$ Control shares are those that would move a shareholder into any one of three ranges of voting power: at least $20 \%$ but less than $33.33 \%$, at least $33.33 \%$ but less than $50 \%$, or $50 \%$ or more. ${ }^{.37}$

Any person acquiring control shares must file an information statement with the target firm containing the identity of the acquirer, a statement of compliance with the statute, the present level of ownership, the range of voting power that the acquirer will possess if the acquisition occurs, and a representation that the acquirer has the financial capacity to make the control share acquisition..$^{58}$ Control shares cannot be voted unless a majority of the shares, excluding those held by interested shareholders, are voted within fifty days of the filing to authorize voting rights. ${ }^{59}$ If the shareholders do not authorize voting rights for the control shares, the target may redeem the control shares. ${ }^{60}$ Shareholder approval is not required if the acquisition is pursuant to a merger or share exchange where the target is party to the agreement. ${ }^{61}$

These voting requirements delay the takeover process. ${ }^{62}$ In addition, complying with federal proxy regulations in connection with the shareholder meeting increases the costs of the acquisition. Hawaii ${ }^{63}$, Minne-

56. IND. Code ANN. $\S \S 23-1-42-1$ to -11 (Burns 1987). The effective date of the statute was postponed from April 1, 1986 to August 1, 1987. However, firms were allowed to opt into the statute after March 4, 1986 by amending their charter or bylaws. Id. $\S 23-1-17-3$ (b). After August 1, 1987, the statute applies unless a coporation opted out. Id. § 23-1-42-5. Indiana also enacted a fair price provision. IND. Code. ANN. $\$ \S 23-1-43-1$ to -24 (Burns Supp. 1986). See supra note 11 and infra note 78 .

57. Id. $\$ 23-1-42-1$. By regulating the acquisition of control shares, not the method, the statute applies to open market purchases and privately-negotiated purchases as well as tender offers. Our study examines the effects of the statute only on tender offers.

58. Id. \& 23-1-42-6.

59. Id. $\S 23-1-42-9$. Interested shares are those owned by the acquirer of the control shares and by the officers and employee directors of the target. Id. $\$ 23-1-42-3$.

60. Id. § 23-1-42-10.

61. Id. $\$ 23-1-42-2(\mathrm{~d})$.

62. By requiring a special stockholder vote, the Indiana statute enables the target's incumbent management to delay the tender offer for a fifty-day period following the disclosure of the acquirer's plans.

63. Haw. Rev. STat. $\S \S 416-171$ to -172 (1986), (effective from Apr. 23, 1985 to July 1, 1987), differed from the Indiana statute in defining the levels of control. A control share acquisition is one in which the potential acquirer moves into the following ranges: at least $10 \%$ but less than $20 \%$, at least $20 \%$ but less than $30 \%$, at least $30 \%$ but less than $40 \%$, at least $40 \%$ but less than a majority, and at least a majority. Id. $\S 416-172(\mathrm{c})(4)$. If the control shares are acquired without first obtaining approval by a majority of the shares not held by the acquiring person or if the tender offer is not consummated within 180 days of shareholder approval, id. $\$ 416-172(e)$, the control shares lose their voting rights and become nontransferable for one year. During the year, the shares are also redeemable. Id. $\S 416-172(\mathrm{~b})$. 
sota, ${ }^{64}$ Missouri, ${ }^{68}$ Ohio, ${ }^{68}$ and Wisconsin ${ }^{67}$ also enacted control share acquisition statutes.

\section{B. Fair Price Statutes}

Maryland's fair price statute ${ }^{68}$ applies to all interested shareholders, those owning directly or indirectly $10 \%$ or more of the corporation, ${ }^{68}$ who plan to engage in a business combination with a domestic firm. Under this statute, all business combinations must be recommended by the board and authorized by a supermajority vote of at least $80 \%$ of the company's total outstanding stock and at least $66.67 \%$ of the total stock held by those other than the interested shareholders. ${ }^{70}$

There are two exceptions to the supermajority voting requirement: The potential acquirer may proceed without supermajority approval if the target's board of directors approves the transaction before the acquirer became an interested shareholder ${ }^{71}$ or if the acquirer pays a "fair price" to remaining shareholders in a second-step freezeout. ${ }^{72} \mathrm{~A}$ fair price is defined as the highest of the following: the highest price paid by the ac-

64. Our study used the Minnesota statute effective from August 1, 1984 to August 1, 1985. Minn. Stat. ANN $\S 302 A .670$ (West 1985) (amended 1985, 1986, 1987). This statute specified the same ranges of voting control as the Hawaii statute. As in the Hawaii statute, if a majority of the disinterested shareholders did not vote their approval, then the control shares became nontransferable and lost their voting rights for one year, during which time they could be redeemed by the corporation. Id. $\S 302$ A.671(1)(b). Minnesota also enacted a fair price statute in 1987. MINN. STAT. ANN. $\S$ 302A.673 (West Supp. 1988).

65. The Missouri statute, effective June 13, 1984, requires approval by two-thirds of the disinterested shareholders before the control shares may even be acquired. Mo. ANN. STAT. $\S 351.407$ (Vernon Supp. 1986) (amended 1987). The statute also requires that the control share acquisition take place within 60 days of obtaining shareholder approval. Id. $\S 351.407 .5(2)$.

66. OHIo Rev. CoDE ANN. $\S \S 1701.01$ (Z)(1), 1701.83.1 (Anderson 1985) (effective Nov. 18, 1982). The Ohio statute uses the same ranges of voting power as the Indiana statute. Id. § $1701.01(\mathrm{Z})(1)(\mathrm{a})-(\mathrm{c})$. Unlike the Indiana statute however, the Ohio statute requires approval by a majority of shares, excluding those owned by the proposed acquirer, officers, and employee directors, id. $\S 1701.01(\mathrm{CC})$, before the control shares may be acquired. Id. $\S 1701.83 .1(\mathrm{E})(1)$. After shareholder approval, the acquirer has 360 days to consummate the acquisition of shares. Id. § 1701.83.1(E)(2).

67. The Wisconsin statute, effective April 24, 1984, contains both control share acquisition and fair price provisions. WIS. STAT. ANN. $\S \S 180.69,180.725$ (West Supp. 1987). The control share acquisition provisions were repealed as of April 22, 1986. 1986 Wis. Laws 995 . A majority vote of the disinterested shareholders was necessary to approve control acquisitions at the following three levels: at least $20 \%$ but less than $34 \%$, at least $34 \%$ but less than a majority, and at least a majority.

68. MD. Corps. \& Ass'NS Code ANN. \$§ 3-601 to -603 (1986) (effective June 21, 1983). While the term "business combinations" commonly refers to mergers and consolidations, the statutory definition includes sales of assets, certain stock issuances, liquidation plans in which the interested shareholder receives anything other than cash, and reclassifications and recapitalizations which increase the interested shareholder's ownership by more than 5\%. Id. $\S$ 3-601(e). Thus, the statute regulates the second step of a two-tier offer but not the first step cash tender offer. The Maryland statute does not apply to business combinations if there was any interested shareholder on July 1,1983, unless the board of directors elects to have the target corporation be bound by the statute. Id. $\S 3-603$ (d).

69. Id. § 3-601(j).

70. Id. \& 3-602.

71. Id. § 3-603(c)(ii).

72. Id. $\S 3-603(\mathrm{~b})$. The consideration received by shareholders in the second step must be in the same form as the consideration paid for other shares in the same class or series. Id. $\S 3-603(\mathrm{~b})(3)$. 
quirer within the two-year period prior to the announcement of the business combination, the highest price paid in the transaction in which the acquirer became an interested shareholder, or the per-share market value on either the announcement date or date the acquirer became an interested shareholder, which may or may not be subject to a multiplier. ${ }^{73}$ The fair price provision thus requires the acquirer to pay shareholders in the second step at least as much as shareholders in the first step received. By preventing the acquirer from freezing out the remaining shareholders at a lower price, the provision lessens the coercive pressure on the shareholder's decision to tender. The majority of states adopting second generation statutes have followed Maryland's approach..$^{74}$ Connecticut, ${ }^{78}$ Georgia, ${ }^{76}$ Illinois, ${ }^{77}$ Indiana, ${ }^{78}$ Kentucky, ${ }^{78}$ Louisiana, ${ }^{80}$ Michigan, ${ }^{81}$ Mississippi, ${ }^{82}$ Virginia, ${ }^{83}$ Washington, ${ }^{84}$ and Wisconsin ${ }^{85}$ had fair price statutes during the period of our study.

73. Id. § 3-603(b)(1)(i)-(iii). The "multiplier" is the highest per-share price paid by the acquirer within the two-year period immediately prior to the announcement of the tender offer, divided by the market value per share of the common stock of the same class or series on the first day of the two-year period on which the acquirer bought any shares of the target common stock. Id. The multiplier is used if it will result in a higher "fair price" figure. $1 d$. $\$ 603(\mathrm{~b})(1)$. Thus, if the price of the target stock has risen since the acquirer began buying stock, the multiplier will be used to determine the "fair price" that minority shareholders will receive in a freezeout.

74. Professor Romano has identified the following reasons for the popularity of fair price statutes: their application to the second stage of a two-tier offer, their greater resistance to constitutional attack, their appeal on fairness grounds because shareholders in both steps are treated equally, and their similarity to the "shark repellent amendments" favored by target managements as a defensive tactic. Romano, supra note 11, at 118-20. By using decision-tree analysis to determine when rational shareholders would adopt each of the three types of antitakeover amendments, and studying the political dynamics of enacting second generation takeover statutes, Professor Romano has developed explanations for when and why certain types of takeover protection are adopted. Professor Romano concluded that shareholders of firms with widely-dispersed ownership will find the adoption of an antitakeover amendment in their interest. This conclusion, she notes, fails to explain why the enactment of these provisions at the state level rather than by the firm is necessary. Id. at 188.

75. Connecticut's fair price statute, CoNN. GEN. STAT. $\$ \S 33-374 a$ to -374 c (1985) (effective June 4,1985 ) conforms to the Maryland provisions. Id. $\$ 33-374 c(d)$.

76. Georgia's fair price statute, GA. CODE ANN. $\S \S 14-2-232$ to -235 (1985) (effective July 1 , 1985), is similar to the Maryland statute but does not use a multiplier to determine the fair price. See $i d$. $\$ 14-2-234$. Firms must opt into the statute through a bylaw amendment for the statute to apply. Id. § 14-2-235.

77. The Illinois fair price statute, Ill. ANN. STAT. ch. 32, If 7.85 (Smith-Hurd Supp. 1987) (effective Aug. 23, 1985), differs from the Maryland statute in that business combinations must be approved by $80 \%$ of all outstanding shares and a majority of the disinterested shares. Id. $\S 32$ I $7.85(\mathrm{~A})(1)$ (e). Acquirers may avoid the shareholder voting requirement by obtaining approval of $66.67 \%$ of the disinterested members of the board of directors, either before or after the acquirer became an interested shareholder. Id. $\S 32$ I 7.85(B)(1).

78. IND. CoDE ANN. $\$ 23-1-43-1$ to -24 (Burns 1987). Unlike Maryland's fair price statute, the Indiana statute does not contain a multiplier. The Indiana takeover statute took effect on August 31 , 1987. However, a corporation's board of directors could opt in before it became generally effective. 1986 Ind. Acts 149 § 3(b).

79. Ky. Rev. Stat. ANn. § 271A.396-.399 (Baldwin 1987) (effective July 13, 1984). The statute's second generation provisions are simliar to the Maryland statute.

80. La. Rev. Stat. ANN. § 12:132 to :134 (West Supp. 1988) (effective July 13, 1984). Louisiana also enacted a control share acquisition statute, effective June 11,1987 . Id. $\$ 12: 135$ to :140.2.

81. Mich. Comp. Laws ANn. $\S 450.1775-84$ (West Supp. 1988) (effective May 29, 1984). Michigan's statute does not use a multiplier to determine the fair price. Id. $\$ 450.1781$.

82. Mrss. Cone ANN. $§ \S 79-25-1$ to -9 (Supp. 1987) (effective July 1, 1985). Mississippi's stat- 


\section{Shareholder Demand Statutes}

Under Pennsylvania's shareholder demand statute, $^{86}$ an interested shareholder or group of shareholders who acquires $30 \%$ of a firm's voting stock in a "control transaction" shareholders that they are entitled to receive, upon written demand to the interested shareholder, the "fair value" of their shares in cash. ${ }^{88}$ The fair value is determined as of the day prior to the beginning of the transaction in which the $30 \%$ control was obtained. The fair price computation includes the premium paid in the first step to acquire control of the corporation. ${ }^{88}$ Requiring the interested shareholder to pay cash to all remaining shareholders converts partial tender offers into any-or-all offers. ${ }^{90}$ In the second step of a two-tier tender offer, the acquirer must still obtain the approval of a majority of the shareholders other than the interested shareholders to effect a merger. ${ }^{91}$ As in the Maryland statute, the shareholder vote requirement is waived if so approved by a majority of the directors excluding those affiliated with the interested shareholder, or if the shareholders receive the highest price paid by the offeror in acquiring shares of

ute parallels the Maryland statute. The three notable differences are an exception from the supermajority voting requirement if the business combination has been approved by at least $80 \%$ of the directors not associated with the acquirer, id., $\$ \S 79-25-3(\mathrm{i}), 79-25-7(\mathrm{~b})(\mathrm{v})(\mathrm{c})$; there is no exception for firms with prior interested shareholders; and an interested shareholder is defined as one owning $20 \%$ or more target stock. Id. § 79-25-3(1)(i).

83. VA. CoDE ANN. $\S \S 13.1-725$ to -728 (1985) (effective June 1, 1985). In addition to the voting exceptions specified in the Maryland statute, Virginia does not require a super-majority vote if the transaction was approved by a majority of the dissinterested directors; if the interested shareholder owned at least $80 \%$ of the voting shares for at least five years prior to the announcement date; or if the shareholder owns at least $90 \%$ of the voting shares. Id. $\S 13.1-727$. Unlike the Maryland statute, the presence of an interested shareholder as of the effective date of the statute does not exempt a firm from the statute.

84. Wash. Rev. Code ANN. $\$ 23$ A.08.425 (Supp. 1988) (effective July 25, 1985). The Washington statute is similar to the Maryland statute but uses a more simple definition of fair price: not less than the highest price paid by the interested shareholder in acquiring the shares during the two years preceding the business combination. Id. $\S 23 A .08 .425(3)(c)$.

85. Wisconsin's fair price provision follows the Maryland statute with two exceptions: no multiplier is used to determine the fair value and there is no exception for firms with a prior interested shareholder. Wis. Stat. AnN. $\$ 180.725$ (West Supp. 1987).

86. PA. Stat. ANN. tit. 15, $\S 1910$ (Purdon Supp. 1987) (effective Dec. 23, 1983) (amended in 1988 to decrease the triggering control level to $20 \%$ ).

87. During the period of our study, a control transaction was defined as any acquisition by an individual or group acting in concert of shares capable of exercising $30 \%$ of the votes for electing directors. Id. $\$ 1910(\mathrm{~B})(1)$, (4).

A shareholder group soliciting more than $30 \%$ of the proxies conceivably could be forced to pay cash for all the remaining shares. See Hersch \& Kearney, supra note 11, at 449. Only those acquisitions involving tender offers were included in our study.

88. Pa. Stat. ANn. tit. 15, § 1910(C), (D), (E) (Purdon Supp. 1987).

89. Id. § 1910(E).

90. Bidders may be reluctant to offer high control premiums under the shareholder demand statutes when they realize that the partial acquisition has become an any-or-all offer that cannot be terminated once they acquired $30 \%$ control.

91. PA. Stat. ANn. tit. 15, $\S 1409.1(C)(1)$ (Purdon Supp. 1987). Similar to the fair price statutes, the shareholder demand guarantee eliminates target shareholder fears that they will be frozen out at a lower price if they do not tender. 
the same class. ${ }^{92}$ The Pennsylvania approach was followed by only two other states, Maine ${ }^{93}$ and Utah. ${ }^{94}$

\section{Review OF the Economic Literature}

Federal and state regulation of tender offers and management defensive tactics that delay the takeover process have been subjected to extensive economic review. ${ }^{95}$ Placing our results in the context of prior empirical findings sheds insight on our analysis and conclusions.

\section{A. Studies of Federal and First Generation State Regulations}

Two empirical studies used similar methodologies to examine the effects of the Williams Act and the first generation of state statutes. Professors Jarrell and Bradley found that the average control premiums paid to target shareholders increased from $32.47 \%$ before the Williams Act to $52.87 \%$ after its enactment. ${ }^{96}$ The average control premiums paid to target shareholders in firms also subject to state regulation was $73.1 \%{ }^{97}$. They concluded that federal and state regulation had a deterrent effect on tender offers. $^{98}$

Guerin-Calvert, McGuckin \& Warren-Boulton examined the effects of federal and state regulation on cash tender offers from 1962-80.99 Their conclusions were consistent with Professors Jarrell and Bradley's finding that the Williams Act and state statutes increased both the average control premiums paid and the number of tender offers with multiple bidders. ${ }^{100}$

92. Id. § 1409.1(C)(2).

93. Me. Rev. Stat. ANN. tit. 13-A, $\S 910$ (Supp. 1987) (effective Sept. 19, 1985). Maine's statute applies to control share acquisitions that entitle the acquirer to control over $25 \%$ of the voting power. The notice period is more specific than the "prompt" notice and response "within a reasonable time" requirements of the Pennsylvania statute. The acquirer must give notice within 15 days of the control transaction, id. $\S 910(3)$, and the shareholders have 30 days after notification to make a written demand to be paid cash for their shares. Id. $\$ 910(4)$.

94. UTAH CoDE. ANN. $\S \S 16-10-2,16-10-76.5$ (1987) (effective Apr. 28, 1986). The Utah statute exempts transactions that have been approved by a majority of the board of directors from complying with the shareholder demand provisions. Id. §16-10-76.5(6)(a).

95. See, e.g., Jarrell, Brickley \& Netter, supra note 23; Jensen \& Ruback, supra note 26.

96. Jarrell \& Bradley, The Economic Effects of Federal and State Regulations of Cash Tender Offers, 23 J.L. \& Econ. 371, 387-404 (1980).

97. Id. at 389 . These increases were statistically significant. Id. at 390 .

98. Id. at 399. While the study acknowledged the various jurisdictional reaches of the state statutes, $i d$. at 378 , it treated the targets as only subject to the regulation of their state of incorporation, id. at 388 n.41. Since one state's regulation of tender offers could extend to targets other than those incorporated under that state's laws, see supra text accompanying note 16, their study did not measure the full effect of each state's laws.

99. Guerin-Calvert, McGuckin \& Warren-Boulton, State and Federal Regulation in the Market for Corporate Control (Jan. 21, 1986) (Economic Analysis Group Discussion Paper on file with the Yale Law Journal).

100. Guerin-Calvert, McGuckin, \& Warren-Boulton found that the average control premium increased from $37.5 \%$ before 1968 to $51.2 \%$ afterwards in states not regulating takeovers. For states with first generation statutes, the average premium after 1968 was $71.5 \%$. Id. at 19 . They also found that federal regulation increased the number of tender offers with more than one bidder from $7.8 \%$ to $17.3 \%$ and that more auctions occurred in states with second generation statutes. Id. at 19 . 
Using regression analysis, this study found that state regulation by principal place of business had a larger estimated effect on the control premium paid than other regulatory methods like state of incorporation. They concluded that the disclosure requirements and delays produced by state regulation increased the probability of an auction. ${ }^{101}$ The authors drew no conclusions, however, as to the effect of the regulations on the success rate of bids. ${ }^{102}$

Since neither of the above studies used a model to predict the number of takeovers that would occur in the absence of the state regulations, the extent of the regulations' deterrence could not be measured. Professor Smiley performed a regression analysis to measure the deterrent effect of first generation statutes on tender offers for targets headquartered or incorporated in states with such regulation. ${ }^{103}$ Professor Smiley observed that $8.5 \%$ fewer takeovers occurred during 1972-1978 than predicted in the absence of state statutes. Thus, Professor Smiley concluded that the delay associated with extending the minimum offer period deterred tender offers. $^{104}$

\section{B. Studies of Antitakeover Amendments}

Empirical studies examining the effect of the adoption of antitakeover amendments on shareholder wealth have provided conflicting evidence. Professors DeAngelo and Rice's study of antitakeover amendments included those requiring supermajority shareholder approval of mergers, consolidations, and sales of assets and those requiring fair price payment to minority shareholders in a second-step freezeout following takeover. ${ }^{105}$ They found weak preliminary evidence that adoption of these amendments entrenched management to the detriment of shareholders. ${ }^{108}$ The authors observed insignificant abnormal returns after the adoption of antitakeover amendments. Professors DeAngelo and Rice, however, could not control for the signalling effects of adopting these amendments. Shareholders may believe that incumbent management would propose antitake-

101. Id. at 20 .

102. When studying unsuccessful takeovers, they acknow]edged that "[t]he proportion of unsuccessful takeovers ... is an incomplete measure of the probability that a company will be taken over. Additional data on the population of corporations in each state and the numbers of attempted and successful takeovers in each state are required for a more complete picture of the effect of regulation on the success of takeovers." Id. We controlled for the population of corporations in each state, therefore, we can draw slightly stronger conclusions about the effect of the second generation statutes on the success rate of takeovers. A more comprehensive study of the effects of the statutes requires a theory that identifies those firms that should be targets. Such a study is beyond the scope of this Note.

103. Smiley, The Effect of State Securities Statutes on Tender Offer Activity, 19 EcoN. INQUIRY 426 (1981).

104. Id. at 432-33. However, this result could be attributed to the inability of the regression to accurately predict the number of takeovers that would occur if there were no state regulation.

105. DeAngelo \& Rice, Antitakeover Charter Amendments and Stockholder Wealth, $11 \mathrm{~J}$. Fin. ECON. 329, 331 (1983).

106. See DeAngelo \& Rice, supra note 105. 
over amendments only if a future takeover were highly probable. Therefore, positive market reactions in anticipation of takeover gains were predicted. ${ }^{107}$ Professors DeAngelo and Rice argued that the absence of positive abnormal returns further supports the management entrenchment hypothesis. ${ }^{108}$

Professors Linn and McConnell, however, found no support for the management entrenchment hypothesis. ${ }^{108}$ They found statistically significant positive average abnormal returns consistently over the periods between board announcement of the amendments' consideration, board approval and the shareholder authorization of the amendments. ${ }^{110}$ These results suggest that shareholders benefit from the adoption of antitakeover amendments but are subject to the same signalling bias as the DeAngelo and Rice results.

The two more recent studies of the economic effect of antitakeover amendments found that adopting specific types of antitakeover amendment has a significant negative effect on the firm's stock price. Professors Jarrell and Poulsen concluded that the statistically significant abnormal negative returns experienced by firms adopting some types of antitakeover amendments were due to the market's characterization of them as detrimental to shareholder interests. ${ }^{111}$ They found that fair price amendments did not cause abnormal returns to decrease significantly. ${ }^{112}$

Relying on the Jarrell and Poulsen results, Professor Pound compared the direct effects of the supermajority and classified-board antitakeover amendments on the frequency and gain from takeovers. ${ }^{113} \mathrm{He}$ concluded

107. Id. at 355 .

108. Id.

109. Linn \& McConnell, An Empirical Investigation of the Impact of 'Antitakeover' Amendments on Common Stock Prices, 11 J. Fin. EcoN. 361, 396 (1983).

110. Id. at 396. One explanation for the increase in target shareholder wealth observed by Professors Linn and McConnell may be that the amendments are contractual arrangements between shareholders and management aimed at eliminating legal interference with beneficial takeovers and alleviating the prisoners' dilemma faced by shareholders once a tender offer is made. See Carney, Shareholder Coordination Costs, Shark Repellents, and Takeout Mergers: The Case Against Fiduciary Duties, 1983 AM. BAR Found. REs. J. 341. This view assumes that shareholders are not apathetic. Compare id. at 388 with Gilson, The Case Against Shark Repellent Amendments: Structural Limitations on the Enabling Concept, 34 STAN. L. REv. 775, 823-27 (1982) (shareholders vote for management proposals even when not in their best interest).

111. Jarrell \& Poulsen, Shark Repellents and Stock Prices: The Effects of Antitakeover Amendments Since 1980, 19 J. Fin. ECON. 127, 155 (1987). In their study of 649 fair price, supermajority, classified-board and authorized-preferred antitakeover amendments proposed from 1979 to 1985, Jarrell and Poulsen observed a statistically significant decrease of $1.25 \%$ in the cumulative abnormal returns. Id. at 143. Supermajority, classified-board, and authorized-preferred stock amendments together produced a statistically significant negative return of $2.95 \%$. Id.

112. Id. Fair price amendments are currently the most popular form of antitakeover amendment. For a discussion of the purpose, effects, and proposals to repeal fair price charter amendments, see Jaenicke, Fair Price Provisions: Background Report D, Investor Responsibility Research Center Report (Feb. 1987) (on file with the Yale Law Journal).

113. Pound, The Effects of Antitakeover Amendments on Takeover Activity: Some Direct Evidence, $30 \mathrm{~J}$. LAW \& ECON. 353 (1987). Pound's study used market regression and portfolio analysis to compare the returns for target firms with either supermajority or classified-board amendments to returns earned by those without these amendments. $I \bar{d}$. at 359 . 
that these amendments have insignificant effects on control premiums, deter takeover bids despite their signalling effect, and make companies more likely to resist and to succeed in resisting takeover attempts than firms without antitakeover amendments. ${ }^{114}$

\section{Studies of the Market Reaction to the Enactment of Second Genera- tion Statutes}

Several studies have examined market reaction to the enactment of state statutes regulating tender offers. An event study by the Office of the Chief Economist of the SEC measured the stock price reactions of Ohio firms to the enactment of the Ohio control share acquisition statute. ${ }^{118}$ The study observed a statistically significant decline in the stock price of $1.68 \%$ for the three days surrounding passage. This represented a loss of $\$ 754$ million to shareholders of Ohio corporations. ${ }^{116}$

A similar event study by Schumann measured the effects of the proposed and the enacted New York takeover statutes on the stock price of New York firms. The first bill, not enacted, contained features of two types of takeover statutes - the control share acquisition and the shareholder demand statutes. The insignificant abnormal negative returns that accompanied announcement of the first bill were followed by significant positive abnormal returns when the bill was vetoed. ${ }^{117}$ These results indicated that the market perceived this bill as detrimental to shareholders of New York corporations. After the bill containing a five-year prohibition against business combinations with a $20 \%$ or more interested shareholder was announced, significant negative abnormal returns were observed. Thus, the overall loss to shareholders of New York corporations as a result of this bill's enactment was estimated at $1 \%$ or $\$ 1.2$ billion. ${ }^{118}$

Professor Romano performed an event study that measured the effect of the enactment of Connecticut's fair price, Missouri's control share acquisition and Pennsylvania's shareholder demand statutes on shareholder wealth. While her study observed a negative effect on stock prices, the results were statistically insignificant. ${ }^{119}$

114. Id. at $363-66$.

115. Office of the Chief Economist, Securities and Exch. Comm'n, Shareholder Wealth Effects of Ohio Legislation Affecting Takeovers (May 18, 1987) (on file with the Yale Law Journal).

116. Id. at 17 .

117. L. Schumann, State Regulation of Takeovers and Shareholder Wealth: The Effects of New York's 1985 Takeover Statutes, Bureau of Economics Staff Report to the Fed. Trade Comm'n. 36-37 (March 1987) (on file with the Yale Law Journal).

118. Id. at 39-40.

119. Romano, supra note 11, at 183-87. Although the enactment of the statutes did not signifcantly affect the stock price of all the New York Stock Exchange firms incorporated in these three states, this does not support the conclusion that second generation statutes have no effect on shareholder wealth. Professor Romano noted that any significant effect of the statutes on these potential targets may not have been discernable among the entire sample of firms because some firms are more likely to be targets than others. Id. at 182 n.133. 
These event studies suggest that the market perceives second generation statutes as detrimental to shareholders. Our study directly tests the effects of the second generation statutes on target firms to determine whether the market's evaluation of the statutes was accurate.

\section{Empirical Tests}

\section{A. Methodology}

We examined cash tender offers made for 242 targets from June 1, 1981 through December 31, 1986. ${ }^{120}$ The Williams Act has been in effect throughout the period of this study and had no effect on comparisons between the test and control groups. We compared tender offers for target firms incorporated in states with one of the three types of second generation statutes ("second generation firms") to tender offers for firms incorporated in states without second generation statutes during the period of our study ("nonsecond generation firms"). ${ }^{121}$

First, we calculated the number of attempted takeovers that involved tender offers for targets incorporated in second generation states and in nonsecond generation states for the periods before and after the effective dates of the statutes, namely, the before and after intervals. ${ }^{122}$ The number of attempted tender offers in each nonsecond generation and second generation state was then calculated as a percentage of publicly-traded firms incorporated in that state. ${ }^{123}$ Since the second generation statutes

120. Tender offers for investment funds, real estate investment trusts, insurance companies, banks, and utilities were excluded from this pool because companies in these regulated industries are usually exempted from general takeover statutes.

ADP Network Services provided a list from the Mergers and Acquisitions Journal database of all cash tender offers for publicly-traded companies with assets greater than $\$ 1$ million. This database included the tender offer terms, announcement date, offer prize, and expiration date. We obtained the state of incorporation of each firm from its 10-K filing with the Securities and Exchange Commission, Financial Stock Guide Service, Directory of Obsolete Securities (1982-1985 eds.); MoOdy's Investors Service, MoOdy's Industrial Manual (1982-1987 eds.); MoOdy's INvesTORs Service, MoOdy's OTG Industrial. Manual. (1982-1987 eds.); MoOdy's Investors Service, Moody's Transportation Manual (1982-1987 eds.); National Quotation Bureau, The National Stock Summary (1982-86 eds.); Standard \& PoOR's Corp., Standard \& Poor's Stock Reports: American Stock Exchange, (1982-1987 eds.); Standard \& POOR's CoRP., STANDARd \& POOR's STOCK REPORTS: NEW YoRK STOCK EXchange (1982-1987 eds.); or STANDard \& POOR's CORP., STANDARD \& POOR'S STOCK Reports: Over THE Counter (1982-1987 eds.). Each firm's state of incorporation was verified by using at least two of the above secondary sources.

121. Several states enacted statutes regulating tender offers after the effective date of our study. See supra note 11.

122. For second generation states the before intervals began with the date in each state when the first generation statute was no longer enforced and ended with the effective date of the second generation statute. The after interval for each state was from this effective date until December 31, 1986.

In all nonsecond generation states, the before period began January 1, 1983 and ended December 1,1984 . This dividing date was determined by calculating the average period following the MITE decision, 29 months, before each state enacted its second generation statutes. The after period for all nonsecond generation states was December 1, 1984 through December 31, 1986.

123. The number of publicly-traded firms on the New York Stock Exchange (NYSE), the American Stock Exchange (ASE) and Over-the-Counter (OTC) in June, 1984 was the base figure for our comparisons. We manually tallied the number of publicly-traded firms incorporated in each state by 
were enacted at different times, the before and after intervals for each second generation state varied in duration and covered different time periods. Some observed differences in the number of attempted tender offers in nonsecond generation states, therefore, can be attributed to the different market conditions that existed in the different second and nonsecond generation intervals being compared. To control for market conditions, we determined the number of tender offers made in all nonsecond generation states during the same before and after intervals used for each second generation state.

Second, we determined the success rate of acquisition attempts involving tender offers. This measures the percentage of companies identified through tender offers as targets that were successfully acquired. We considered an acquisition to be successful if there was a change in control of the target, but this change did not have to be accomplished through a tender offer. To measure the effects of the statutes from the perspective of bidders, we also determined the percentage of successful tender offers ${ }^{124}$ before and after the enactment of the statutes.

Third, we determined the percentage of target firms for which multiple bids $^{125}$ and auctions ${ }^{128}$ occurred. These indicate the extent that statutory delay induced the bidder to increase the price or enabled subsequent free riders to enter the bidding process.

Fourth, we determined the average control premium paid to target shareholders. This is the average increase in the price paid per share as a result of the tender offer, or the difference between the tender price paid and the price of each target's stock forty trading days before the announcement of the tender offer, expressed as a percentage of the latter, adjusted for stock dividends and splits. ${ }^{127}$

Fifth, we calculated the cumulative abnormal returns paid to target

using Standard \& POOR's Gorp., Standard \& POOR's StOck RePorts: New York Stock Exchange (1984), Standard \& Poor's Corp., Standard \& Poor's Stock Reports: AmeriCan Stock Exchange (1984), and Standard \& Poor's Corp., Over the Counter (1984). We excluded firms principally engaged in specifically regulated industries discussed supra note 120 . Without adjusting for the total number of firms that could be affected by a statute in each state, the comparisons would be skewed towards finding a greater change in the second generation states because they generally have fewer incorporations than the nonsecond generation states.

124. We used Jarrell and Bradley's definition: a tender offer is successful if an acquirer purchased more than $50 \%$ of the shares sought. In an any-or-all tender offer, the number of target shares outstanding was used as the number of shares sought. Jarrell \& Bradley, supra note 96, at 388 n.40.

125. We defined a multiple bid as a takeover attempt involving only one bidder who increased its tender offer price.

126. We defined an auction as a takeover attempt involving an initial tender offer followed by at least one other bidder making a tender offer, a merger proposal, or a recapitalization proposal. Defensive techniques employed by target management that did not change the ownership of the firm and actions pursuant to a shark repellent amendment did not constitute an auction unless they resulted in another offer to target shareholders.

127. We obtained the tender offer price was obtained from the Mergers and Acquisitions Journal database; the price of the target's stock was obtained from the DAILY STOck PRICE Record for the American and New York Stock Exchanges. 
shareholders in each group using a market model regression. ${ }^{128}$ The daily abnormal returns of each firm were determined for the period between 40 trading days before and 90 trading days after the tender offer was announced. ${ }^{129}$ The daily abnormal returns of the firms in each group were then averaged to arrive at the daily average residual of the portfolio. The daily average residuals were then cumulated for each day of the test period to determine the portfolio's cumulative abnormal returns (CARs). The CARs measure the changes in each firm's market price that are not attributable to changes in market conditions. We used the $95 \%$ confidence interval for statistical significance. ${ }^{130}$

We calculated control premiums and cumulative abnormal returns for one test group ${ }^{131}$ and two control groups. ${ }^{132}$ The first control group, the "second generation control group," consisted of attempted tender offers initiated in states that adopted second generation statutes after the applicable first generation statutes were enjoined, declared unconstitutional, or repealed, but before the state enacted a second generation statute. ${ }^{133}$ The

128. Market model regression analysis was developed in Fama, Fisher, Jensen and Roll, The Adjustment of Stock Prices to New Information, 10 INT'L Econ. Rev. 1 (1969). The standard market model regression was used to estimate abnormal returns:

$\hat{\mathrm{R}}_{\mathrm{it}}=\hat{\alpha}_{\mathrm{i}}+\hat{\mathrm{B}}_{\mathrm{i}} \mathrm{R}_{\mathrm{mt}}$ where $\hat{\mathrm{R}}_{\mathrm{jt}}$ is the estimated return of firm $i$ at time $t, \hat{\boldsymbol{\alpha}}_{i}$ is the estimated itercept term of firm $i, \hat{B}_{i}$ is the estimated slope of the return on stock $i$ and the market return regression, and $R_{m i}$ is the market return at time $t$.

Using a FORTRAN program, the $\hat{\mathbf{\alpha}} ; \mathrm{i}$ and $\hat{\mathbf{B}}_{i}$ terms were estimated by using the firm's actual returns for the periods from $\mathrm{t}=-100$ to $\mathrm{t}=-40^{\mathrm{i}}$ and $\mathrm{t}=90$ to $\mathrm{t}=135$. The specific regressions were then run for each firm for the period from $t=-40$ to $t=90$ and the Rit was calculated. The error terms, or residuals, $e_{i t}$, represent the differences between the expected returns and the actual returns. Thus, Rit $=\hat{\mathrm{R}} i t+\mathrm{e}_{\mathrm{it}}$. The FORTRAN program used the Center for Research in Security Prices, University of Chicago (CRSP) database (1986) to obtain the daily stock returns.

129. See Brown \& Warner, Using Daily Stock Price Returns: The Case of Event Studies, 14 J. FIN. ECON. 3 (1985) (study examining potential difficulties of using daily stock return data in event studies concluded that results using daily stock data are straightforward).

130. A $95 \%$ confidence interval means that differences between the test and control group results are considered statistically significant only if there is less than a $5 \%$ probability that the differences are due to sampling error rather than real differences between the groups.

131. The test group consisted of tender offers involving NYSE or ASE firms incorporated in second generation states that were the targets of tender ofters announced during the effective periods of the statutes. OTC firms were excluded from the samples because their stock price information is not available on the CRSP tapes.

Tender offers were also excluded from this test sample if the target firm opted-out of the state statute. Two shareholder demand firms opted out of the statutes. This information was obtained through SEC filings, corporate reports of charter and bylaw amendments maintained by the New York Stock Exchange library, computer searches (NEXIS library, Papers file), and Wall Street Journal articles. The information was verified by letter or telephone conversations with corporate officers. Because of the small number of takeovers in this sample, we aggregated the three types of second generation statutes. There was one control share acquisition firm, nine fair price firms, and six shareholder demand firms, for a total of 16 firms in the test sample.

132. We excluded target firms with antitakeover charter amendments similar to the fair price, shareholder demand, or a supermajority voting requirements. Therefore, our resuits were not confounded by the market's reaction to shark repellent amendments.

133. The beginnings of the control periods differ because first generation statutes were no longer enforced at different times. The date of the MITE decision, June 23, 1982, began the control period in each state unless the first generation statute was earlier invalidated in that state. The ends of the control periods differ since the second generation statutes were not enacted simultaneously. There were 6 control share acquisition firms, 10 fair price firms, and 1 shareholder demand firm, for a total 
other control group, the "nonsecond generation control group," consisted of tender offers for targets incorporated in states that did not enact second generation statutes during the period of our study. We pair-matched firms in the nonsecond generation control group to firms in the test group by industry, stock exchange, and announcement date. ${ }^{134}$

We compared the control premiums of the test group to the control premiums of the second generation control group in one t-test. A second ttest was performed to compare the control premiums of the test group with those of the nonsecond generation control group. We also performed t-tests on the cumulative abnormal returns for the three portfolio abnormal returns cumulated to the 90th day (CAR90) to determine whether there was a significant difference in the abnormal returns earned by the target shareholders in any of the three groups.

\section{B. Empirical Evidence}

There was an increase in the number of attempted takeovers under all three types of second generation statutes and in states without second generation statutes. However, the increase in takeovers attempted for second generation states was smaller than for nonsecond generation states $38.46 \%$ compared to $85.71 \%$. This difference is less when the total number of targets was calculated as a percentage of publicly traded firms $1.54 \%$ in second generation states as compared to $2.46 \%$ in nonsecond generation states. Among the second generation states, shareholder demand states experienced the largest increase in the number of takeovers attempted. The results are summarized in Table 1.

of 17 firms in the second generation control group. This control group was not matched to the test group by industry or size. Unlike a capital asset pricing model regression, the results of a study based on the predicted errors of a market model regression are not biased by failing to control for firmspecific variables. Jain, Relation Between Market Model Prediction Errors and Omitted Variables: $A$ Methodological Note, 24 J. Acct. REs. 187 (1986).

134. This control group consisted of 16 firms and was used to account for the confounding factors that might result from the comparison between takeovers in test and control groups separated over time. For a discussion of the significance of size and industry, see Carleton \& Lakonishok, The Size Anomaly: Does Industry Group Matter?, 12 J. PORTFolio MGT. 36 (1986). A control tender offer was matched to the test tender offer if the announcement dates were within one year of each other. The industry matching was according to each firm's standard industrial classification (SIC). 
Table 1

Increase In Number of Takeover Attempts for Before/After Intervals

Groups

Control Share

Fair Price

Shareholder Demand

All Second

Generation

States

Nonsecond

Generation

States
Increase Relative to Publicly-

Before After Increase (\%) $\quad$ Traded Firms (\%)

$\begin{array}{llll}6 & 8 & 33.33 & 0.84\end{array}$

$\begin{array}{llll}18 & 18 & 0 & 0\end{array}$

$\begin{array}{llll}2 & 10 & 400.00 & 6.66\end{array}$

$\begin{array}{llll}26 & 36 & 38.46 & 1.54\end{array}$

$\begin{array}{llll}63 & 117 & 85.71 & 2.46\end{array}$

To control for differences in market conditions over the period of our study, ${ }^{135}$ we compared the number of takeover attempts in each second generation state before and after the enactment of the second generation statutes with takeover attempts in all nonsecond generation states during the same time period, adjusting for the number of publicly-traded firms in each state. These results are shown in Table 2.

135. See supra note 122 and accompanying text. 
Table 2

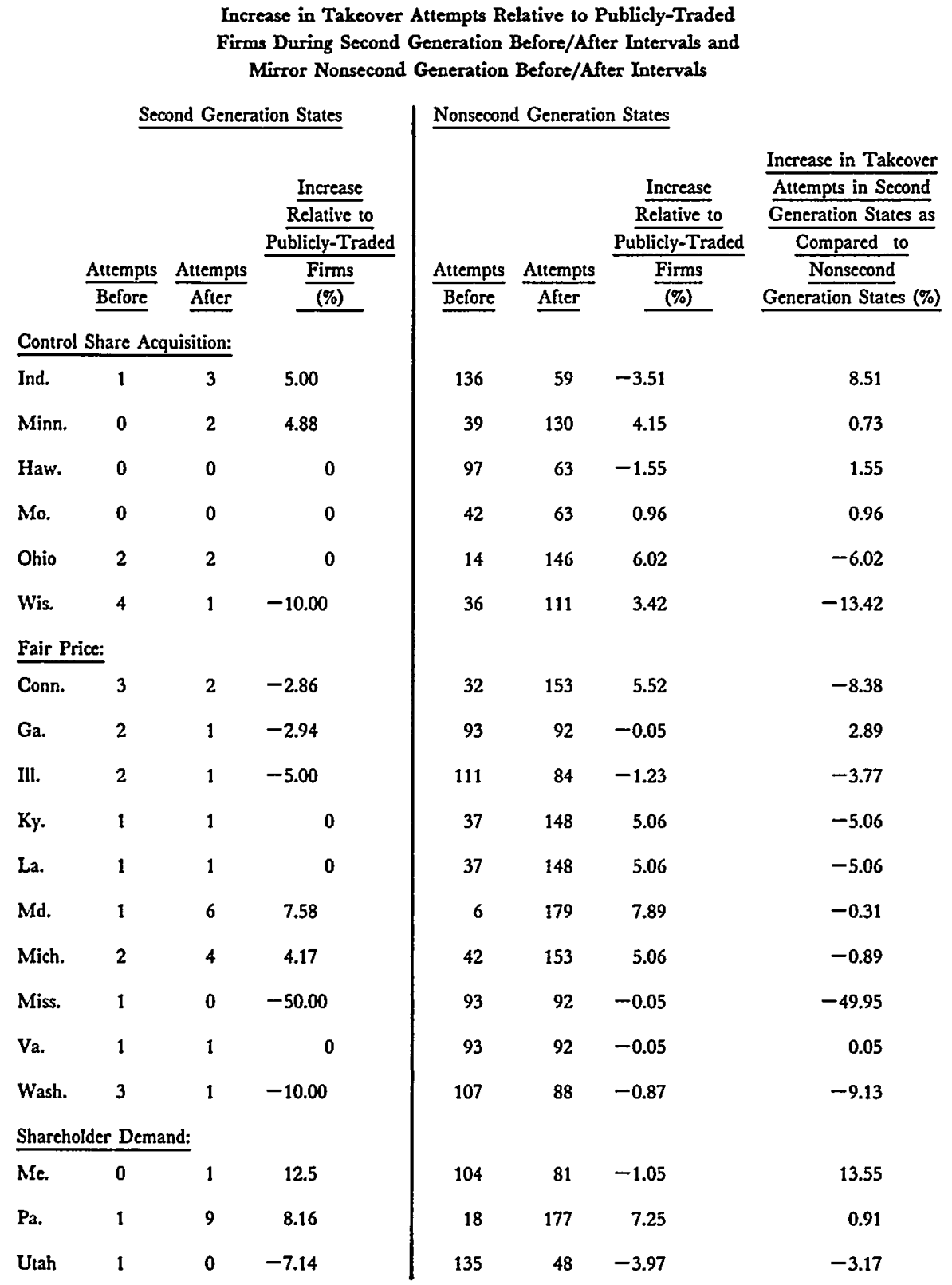

These results do not differ significantly from those shown in Table 1 when market conditions were not controlled. The increase in takeover attempts was greater in eight states when the second generation statutes applied. The increase in takeover attempts in second generation states was less than the increase of nonsecond generation states in eleven states.

The results of our second measure, percentage of successful acquisitions involving tender offers, are shown in Table 3. This measure is an indica- 
tion of the percentage of those firms identified as targets through a tender offer that were ultimately taken over.

Table 3

Successful Target Acquisitions Involving Tender Offers

Type of Statute

\begin{tabular}{|c|c|c|c|c|}
\hline \multicolumn{2}{|c|}{ Before } & \multicolumn{2}{|c|}{ After } & Increase (\%) \\
\hline Percentage & Actual & Percentage & Actual & \\
\hline 100.00 & $(6 / 6)$ & 75.00 & $(6 / 8)$ & -25.00 \\
\hline 100.00 & $(18 / 18)$ & 100.00 & $(18 / 18)$ & 0 \\
\hline 100.00 & $(2 / 2)$ & 90.00 & $(9 / 10)$ & -10.00 \\
\hline 100.00 & $(26 / 26)$ & 91.67 & $(33 / 36)$ & -8.33 \\
\hline 80.95 & $(51 / 63)$ & 95.73 & $(112 / 117)$ & 14.78 \\
\hline
\end{tabular}

States

There were no instances in the period before the enactment of second generation states in which a target was not acquired. Therefore, the occurrence of unsuccessful acquisition attempts after the enactment of the statutes caused the percentage of successful acquisitions to decline. By contrast, the acquisition success rate increased in nonsecond generation states over roughly the same time period. While this may suggest that second generation statutes, particularly the control share acquisition statute, helped targets remain independent, the sample size is too small to support such a conclusion. Factors not measured in our study such as target litigation or poison pills could also account for changes in the acquisition success rate. 
To measure changes in the success rate from the perspective of bidders, we calculated the percentage of tender offers made during the before and after intervals that were successful. The results are shown below.

Table 4

Successful Tender Offers

Type of Statute

Control Share

Before

\begin{tabular}{r}
\hline Percentag \\
\hline 75.00 \\
89.47
\end{tabular}

\begin{tabular}{|c|c|}
\hline \multicolumn{2}{|c|}{ After } \\
\hline Percentage & Actual \\
\hline
\end{tabular}

Increase (\%)

Fair Price

66.67

60.00

$(17 / 29)$

$-15.00$

Shareholder Demand

$(17 / 19)$

85.00

$(9 / 11)$

$-4.47$

All Second Generation

States

83.33

$(2 / 3)$

81.82

15.15

Nonsecond Generation

States

$$
\begin{array}{lllll}
75.76 & (50 / 66) & 75.94 & (101 / 133) & -0.18
\end{array}
$$

The success rate of tender offers decreased for second generation firms after the enactment of the statutes, while the success rate was almost constant for nonsecond generation firms. Among second generation firms, the success rate decreased for both control share acquisition and fair price firms and increased for shareholder demand firms. The unusually large number of successful offers in shareholder demand states resulted in an overall higher success rate for second generation firms. The presence of a control share acquisition or fair price statute appeared to decrease the likelihood of a successful offer.

The third measure revealed an increase in the percentage of multiple bids under both the fair price and shareholder demand statutes and a decrease under the control share acquisition statutes. Overall, the percentage of multiple bids increased in second generation states while it declined in nonsecond generation states. The results are summarized in Table 5.

Table 5

Takeovers Involving Multiple Bids and Auctions

\begin{tabular}{|c|c|c|c|c|c|c|c|}
\hline \multirow[t]{2}{*}{ Type of Statute } & \multicolumn{2}{|c|}{ Multiple Bids (\%) } & \multicolumn{2}{|c|}{ Auctions (\%) } & \multicolumn{2}{|c|}{$\begin{array}{l}\text { Multiple Bid } \\
\text { and Auctions (\%) }\end{array}$} & \multirow[t]{2}{*}{$\frac{\frac{\text { Increase in }}{\text { Multiple Bids }}}{\text { and Auctions (\%) }}$} \\
\hline & Before & After & Before & After & Before & After & \\
\hline Control Share & 33.33 & 25.00 & 33.33 & 12.50 & 66.67 & 37.50 & -29.17 \\
\hline Fair Price & 11.11 & 16.67 & 22.22 & 22.22 & 33.33 & 38.89 & 5.56 \\
\hline Shareholder Demand & 0 & 30.00 & 50.00 & 20.00 & 50.00 & 50.00 & 0 \\
\hline $\begin{array}{l}\text { All Second Generation } \\
\text { States }\end{array}$ & 15.38 & 22.22 & 26.92 & 19.44 & 42.31 & 41.67 & -0.64 \\
\hline $\begin{array}{l}\text { Nonsecond Generation } \\
\text { States }\end{array}$ & 19.05 & 15.38 & 9.52 & 20.51 & 28.57 & 35.90 & 7.33 \\
\hline
\end{tabular}


The percentage of auctions declined under the control share acquisition and shareholder demand statutes and remained the same under the fair price statutes. Overall, the incidence of auctions declined after the enactment of the statutes in second generation states while it increased in nonsecond generation states. Calculating the percentage of targets experiencing multiple bids or auctions revealed almost no change under the second generation statutes compared to a small increase in nonsecond generation firms over roughly the same period. ${ }^{136}$

Table 6 presents the results of our fourth measure-average control premiums for the test and control groups. ${ }^{137}$

Table 6

Control Premiums

\begin{tabular}{|c|c|c|c|}
\hline Group & Number of Firms & $\frac{\text { Average Control }}{\underline{\text { Premium (\%) }}}$ & $\frac{\text { Range of }}{\text { Premiums Paid (\% }}$ \\
\hline Nonsecond & & & \\
\hline Generation Control & 15 & 50.89 & $3.26-106.70$ \\
\hline Second & & & \\
\hline Generation Control & 17 & 62.96 & $9.47-150.00$ \\
\hline Test & 15 & 47.76 & $13.95-129.02$ \\
\hline
\end{tabular}

Groups

I Statistic $\quad$ Probability Samples from Same Population (\%)

Test and Nonsecond

Generation Control

77.03

Test and Second

Generation Control

The average control premium ${ }^{138}$ in states after the first generation statutes were no longer applied but before the states enacted second generation statutes was approximately $62.96 \%$. The average control premium paid under second generation statutes was $47.76 \%$ and the average premium paid to shareholders of nonsecond generation firms was $50.89 \%$. While the average control premiums paid in the second generation control group appears to be higher than the average control premiums paid in the

136. Using the average enactment date of the statutes, December 1, 1984, as the dividing point for both second and nonsecond generation states produced opposite results.

137. A t-test was performed to determine whether to accept or reject the hypothesis that the true population means of the control and test groups are equal. We used the t-distribution to perform the test because it is more reliable than a normal distribution when there are fewer than 30 observations. If the population means were the same, then the existence of the second generation statutes had no effect on the control premiums received by target shareholders in the takeover.

138. We excluded one firm with a negative control premium from the test group. The offer, made below the $\mathrm{t}=-40$ price, was uncontested and successful. There were no unusual events reported concerning the target to account for this lower tender offer price or its success. We then omitted the match for this firm from the nonsecond generation control group. 
test and nonsecond generation control groups, the difference is not statistically significant.

The fifth measure are the cumulative abnormal returns. ${ }^{139}$ The CAR90 was $9.4 \%$ for the nonsecond generation control group, $62.9 \%$ for the second generation control group, and $17.3 \%$ for the test group. Figures 1-6 plot the GARs along the time intervals surrounding the announcement date of the tender offer for each of the three samples for the 40 trading days before the announcement of the tender offer to 60 trading days afterwards and for the 40 trading days before the announcement of the tender offer to 90 trading days afterward. ${ }^{140}$ T-tests were performed to determine whether the GAR90 for each group represented a significant abnormal return.

139. We calculated the cumulative abnormal returns excluding one firm with a negative control premium from the test group and its match from the nonsecond gencration control group. See supra note 138.

140. The t-statistics for the CAR90 of the nonsecond generation control group, the second generation control group and the test group were $1.34,3.83$, and 2.26 respectively. 
Figure One - Test Group

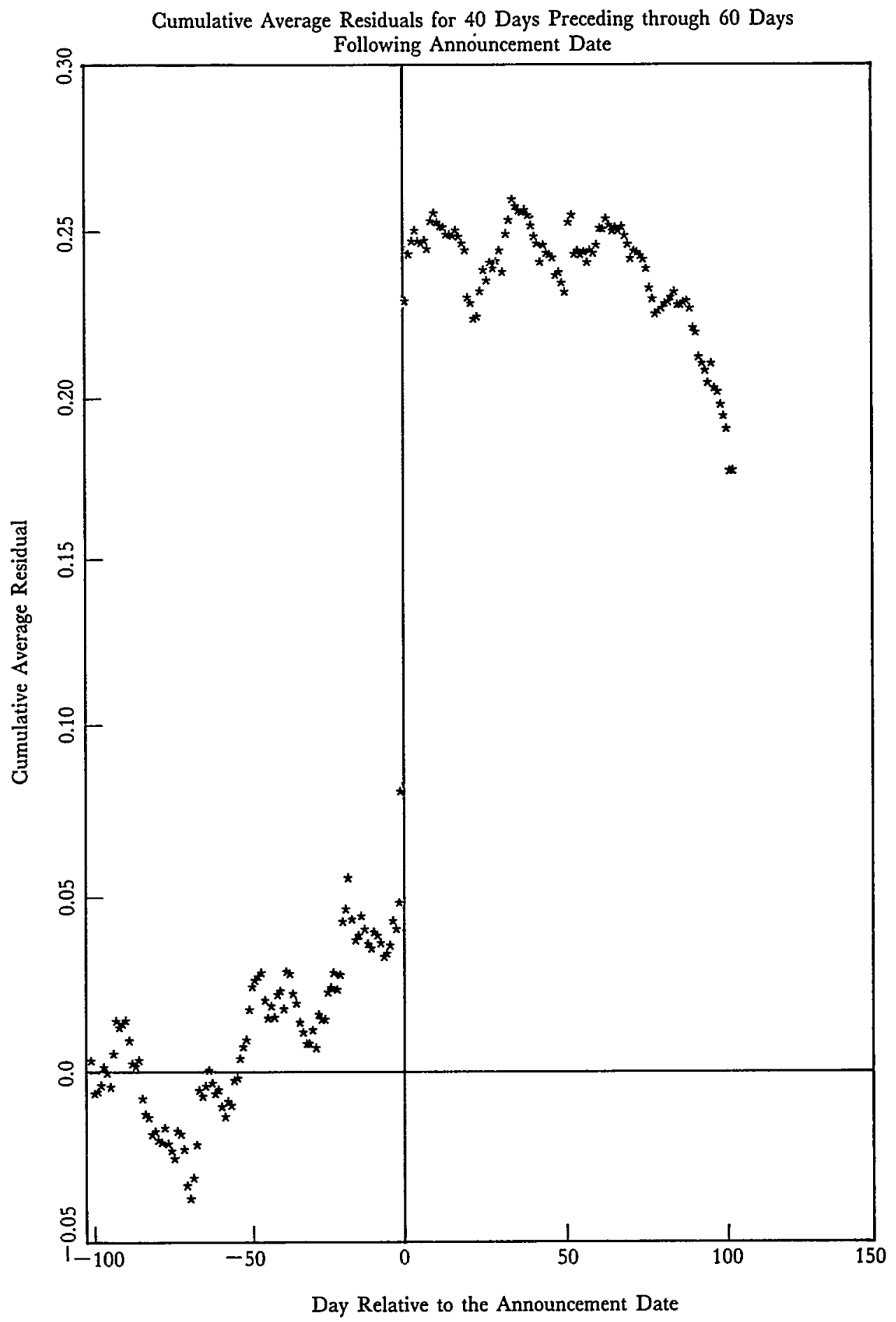


1988]

Figure Two - Second Generation Control Group

Cumulative Average Residuals for 40 Days Preceding through 60 Days

Following Announcement Date

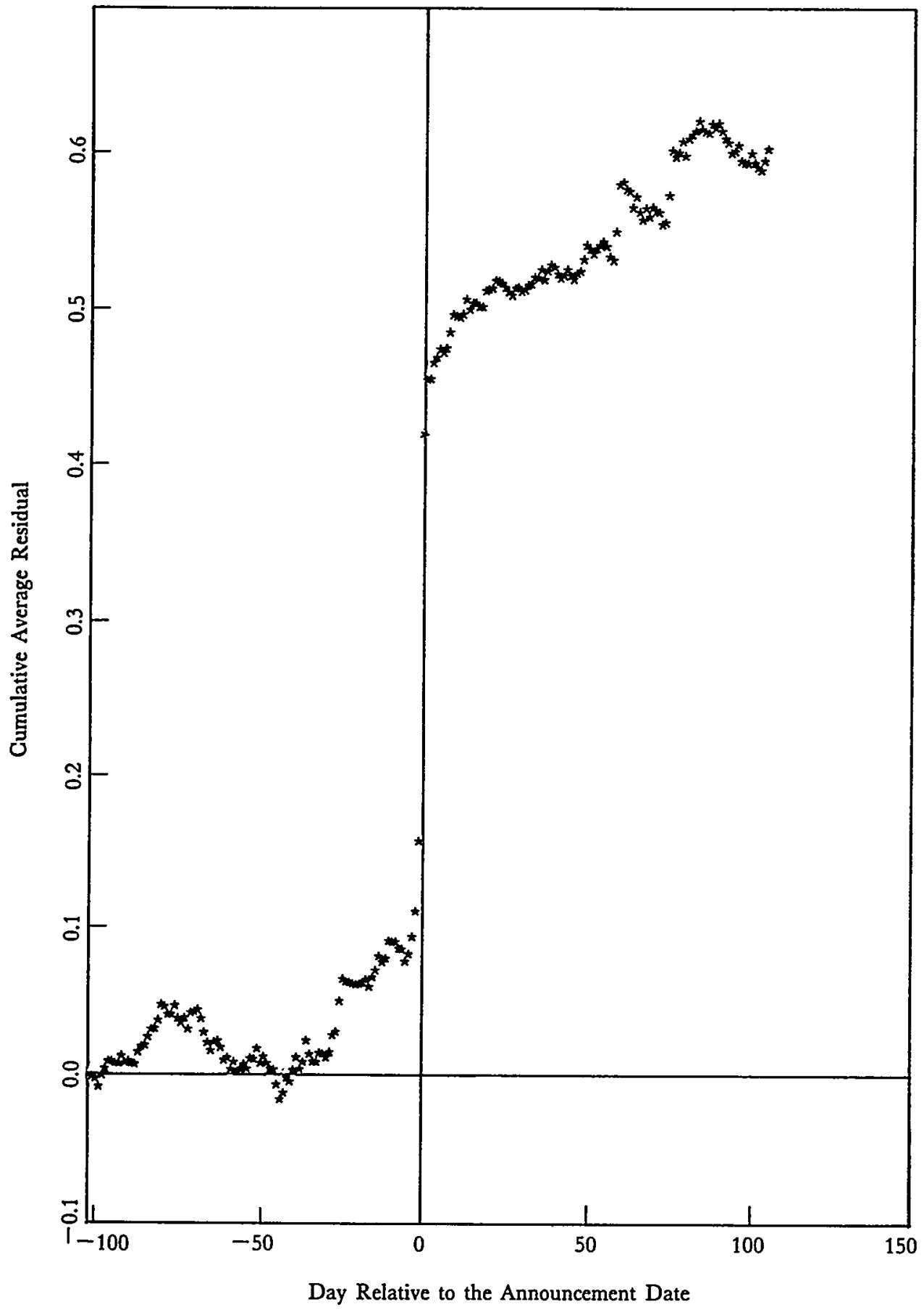


[Vol. 97: 1193

Figure Three - Nonsecond Generation Control Group

Cumulative Average Residuals for 40 Days Preceding through 60 Days

Following Announcement Date

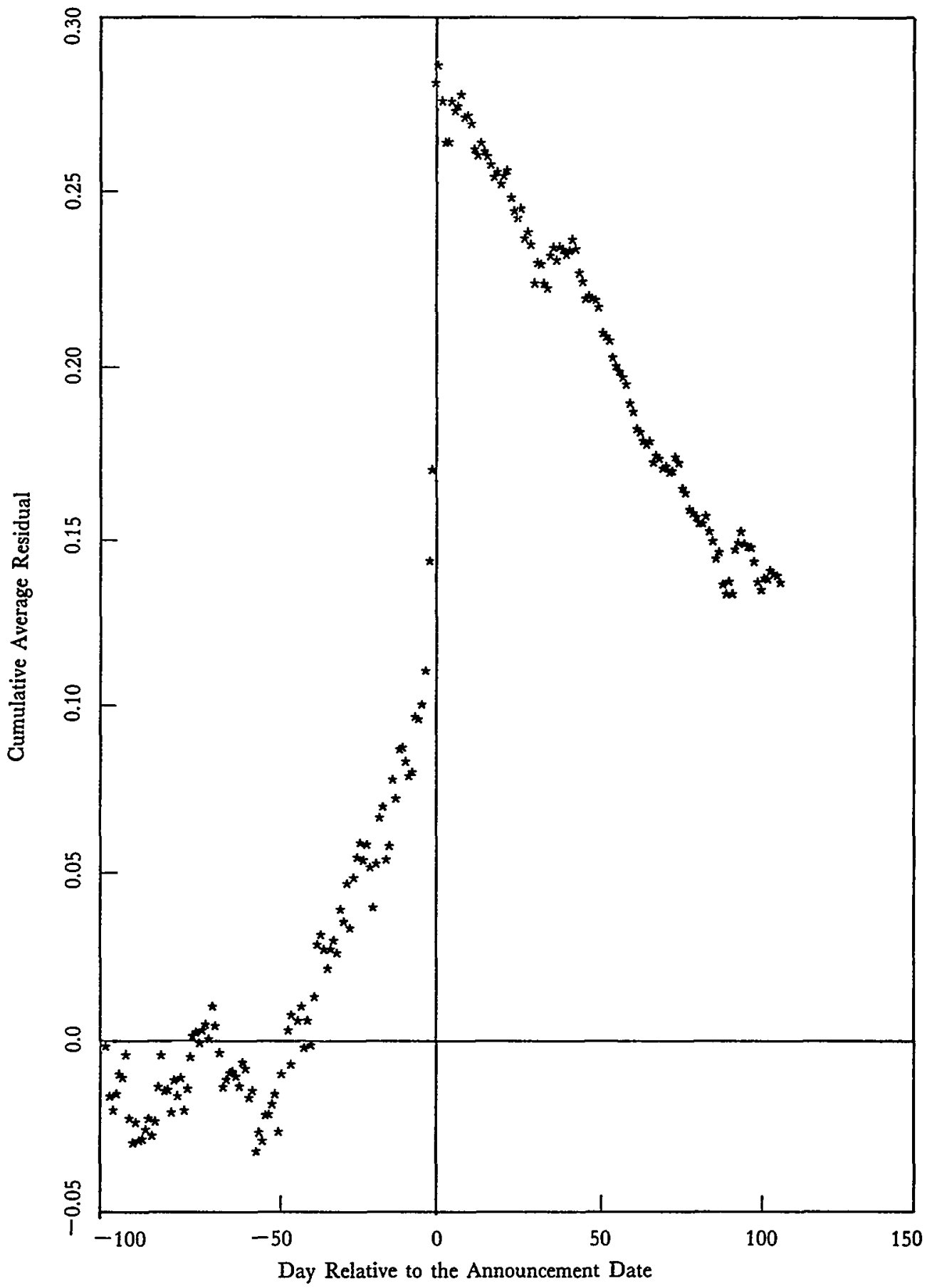


Figure Four - Test Group

Cumulative Average Residuals for 40 Days Preceding through 90 Days Following Announcement Date

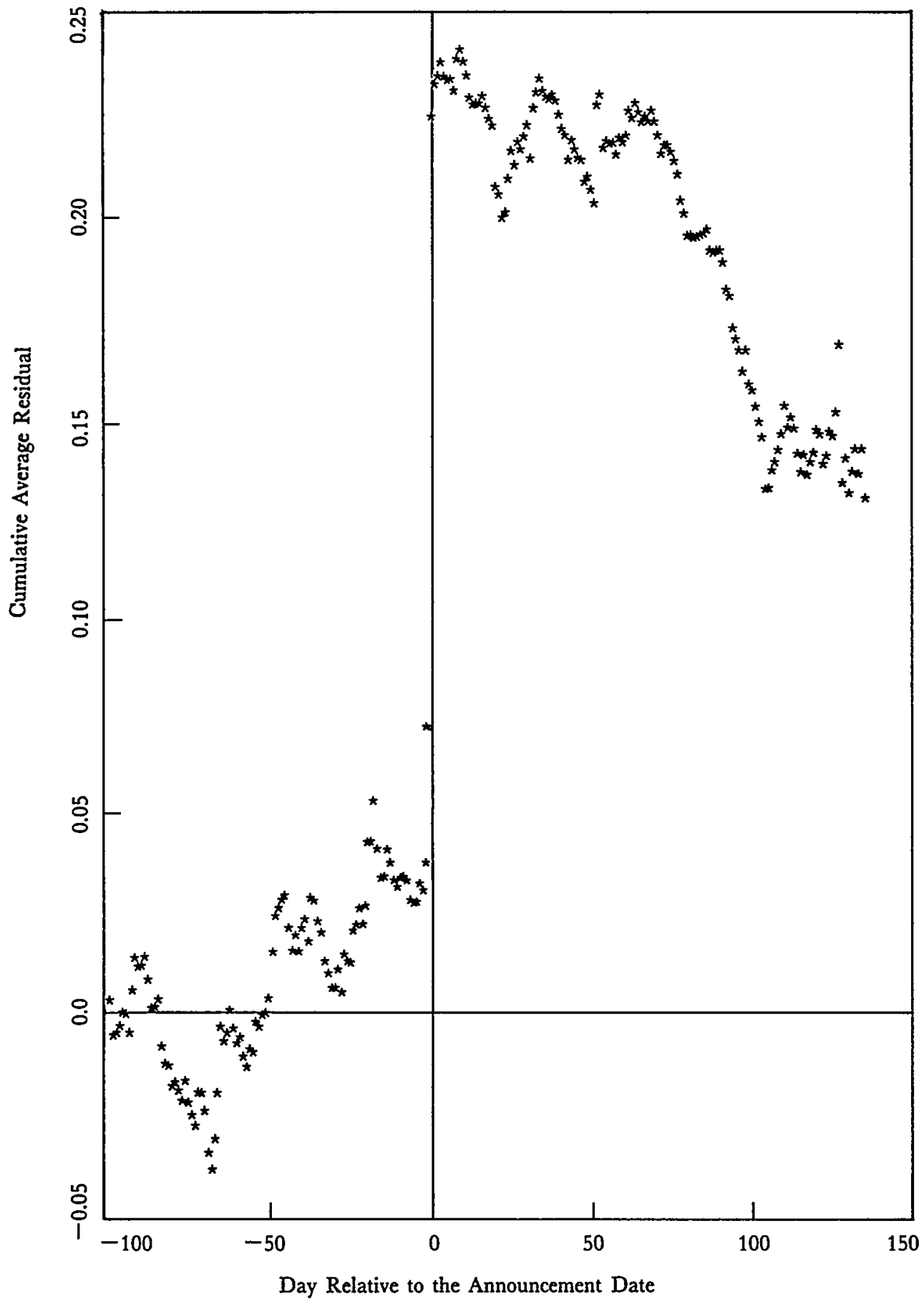


Figure Five - Second Generation Control Group

Cumulative Average Residuals for 40 Days Preceding through 90 Days

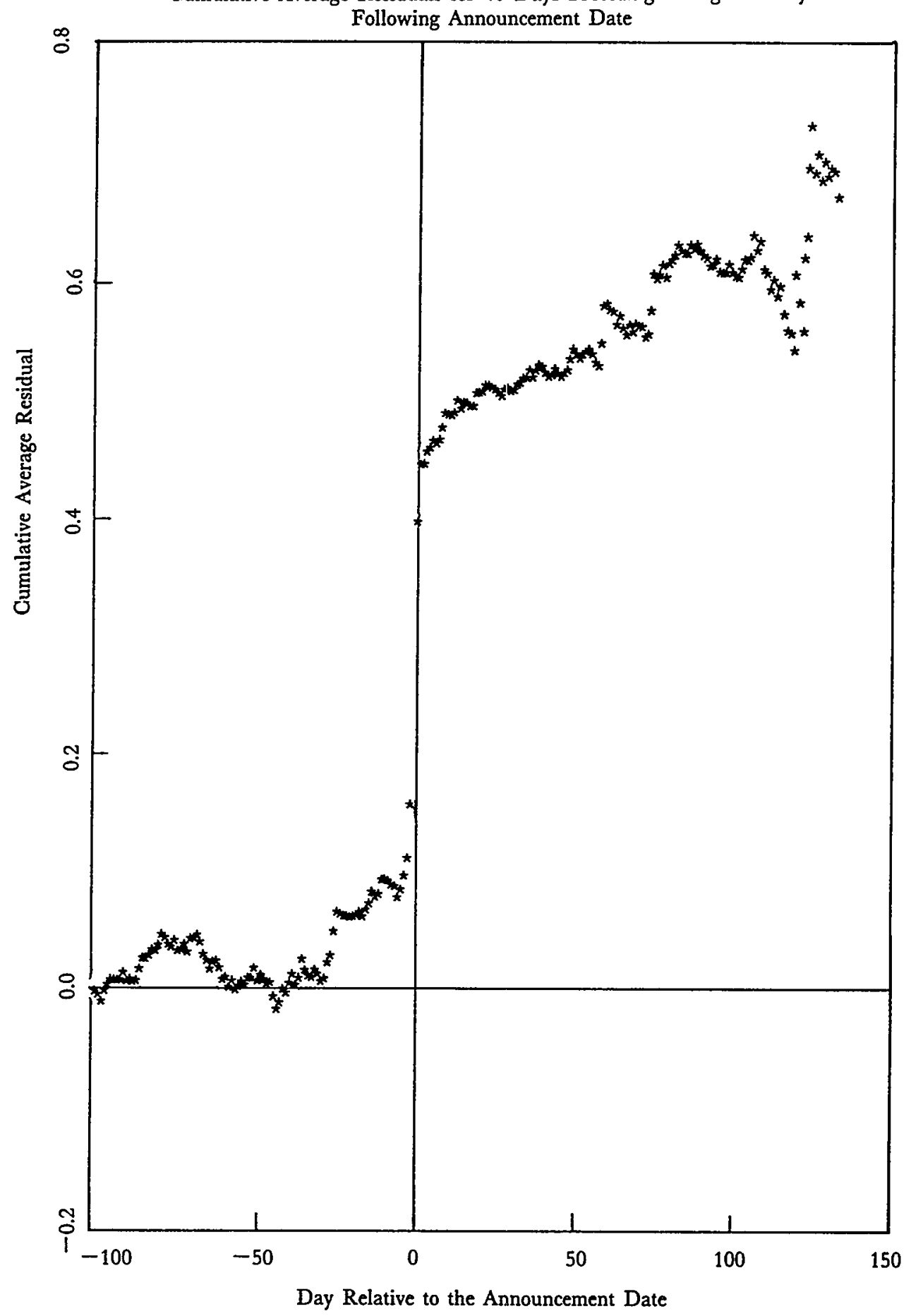


1988]

Second Generation Statutes

Figure Six - Nonsecond Generation Control Group

Cumulative Average Residuals for 40 Days Preceding through 90 Days

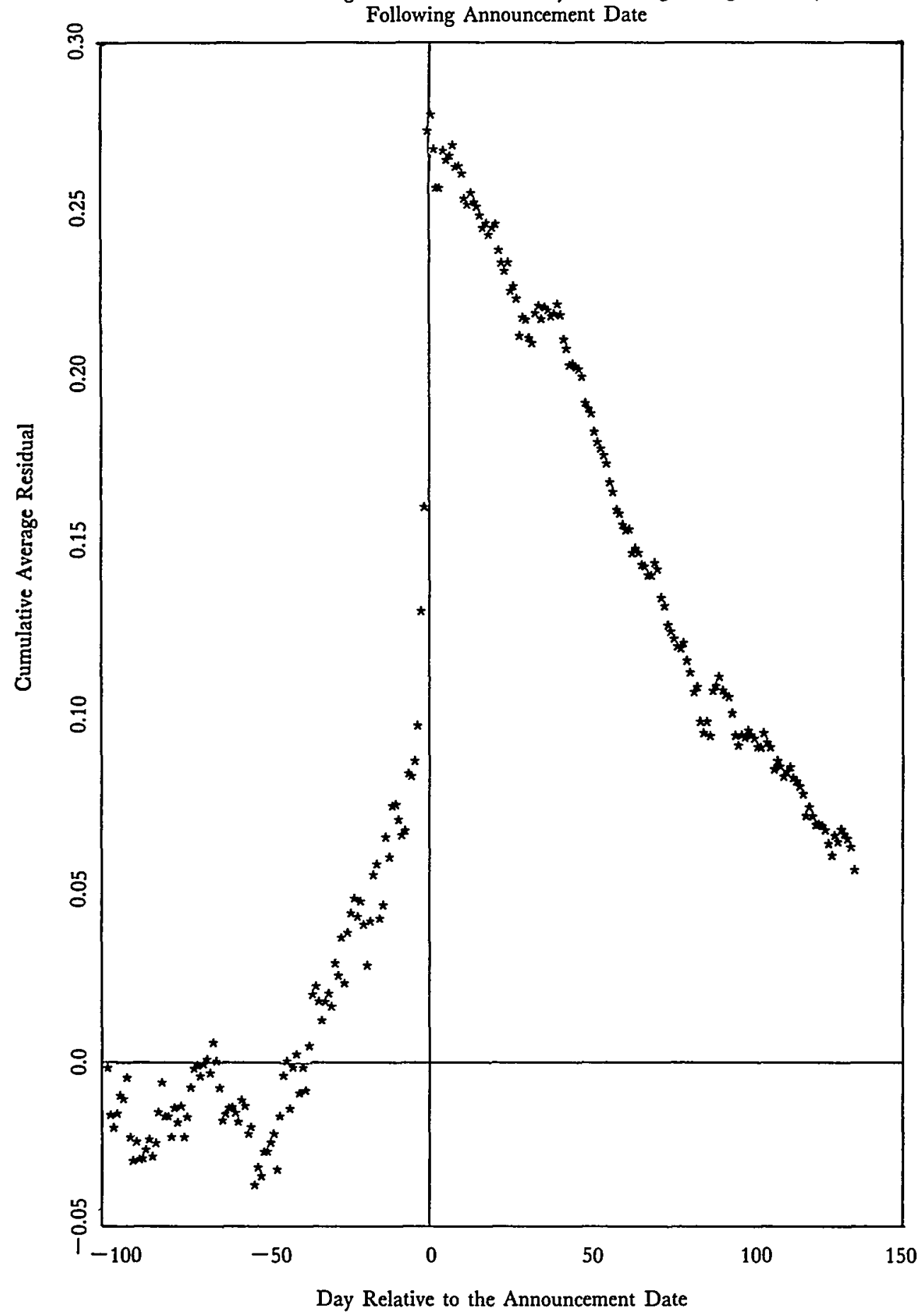


At the end of the period, the cumulative abnormal returns for both the test and second generation control groups were indeed statistically different from zero. The GAR90 of the nonsecond generation control group, however, was not statistically significant. By comparing the GAR90 for the test group with the GAR90 for the nonsecond generation control group, it appears that the presence of second generation statutes increased returns to target shareholders. Yet the CAR90 of the second generation control group was much higher and also statistically significant.

This suggests that the statutes themselves may not be responsible for producing abnormal returns for a longer period than under no state regulation. Indeed, when we examined the CAR60 for each of the three groups, the cumulative abnormal returns were all significantly greater than zero. When we examined the three portfolio CARs, the only pattern discerned was in the second generation control group, where the bulk of the abnormal returns occurred by the 60th day after the announcement date. More auctions and multiple bids occurred in the test and second generation control groups than in the nonsecond generation control group. Since auctions and multiple bids delayed the acquisition of these targets there were more residuals remaining to be cumulated in the test and second generation control portfolios. Since fewer firms were still being publicly traded at the end of the study period in the the nonsecond generation control group, ${ }^{141}$ this may be the best explanation for the insignifcant CAR90. ${ }^{142}$

\section{ANalysis of Results}

This study was designed to provide direct evidence about the effects of second generation statutes. The results of our study indicate that the second generation statutes have similar effects on shareholder wealth as do comparable antitakeover amendments. ${ }^{143}$ The second generation statutes appear to have decreased the threat of takeovers. While both second and nonsecond generation firms experienced an increase in takeover attempts over the period of our study, the increase for second generation firms was smaller than for nonsecond generation firms. This tends to support the

141. At $\mathrm{t}=90$, average residuals were being calculated and cumulated within the portfolio for the two remaining firms in the nonsecond generation control group, the three firms in the second generation control group and the six firms remaining in the test group.

142. It may be possible that matching the nonsecond generation control group with the test group gave us a sample that did not represent nonsecond generation firms. For comparison, we compiled a random sample consisting of 25 nonsecond generation firms. We numbered every nonsecond generation firm that was the target of a tender offer initiated after December 1, 1984. We then selected 40 firms using the random numbers table in E. Mansfield, Statistics for Business Economics: Methods and Applications, at A14 (2d ed. 1983). Since some of the observations necessary to estimate the firm's specific $\hat{\boldsymbol{\alpha}}$ and $\hat{\mathrm{B}}$, see supra note 128 , were not available, 15 firms were excluded from the random portfolio. Unlike the matched nonsecond generation control group, the CAR90 of the random nonsecond generation portfolio was $41.48 \%$, significantly greater than zero.

143. See supra text accompanying notes 105-114. 
prediction that rules that impose delays on the takeover process will deter takeovers because they discourage searching activity, ${ }^{144}$ and tends to contradict the hypothesis that facilitating auctions will not reduce the number of takeovers because there is an excessive level of search for targets. ${ }^{\mathbf{1 4 5}}$ The percentage of takeover attempts in which the target successfully remained independent increased both in the absolute and relative to nonsecond generation firms. Second generation statutes may have contributed to the ability of target management to resist takeovers. The decline in the percentage of successful acquisitions and the percentage of successful tender offers under second generation statutes may have been a deterrent that contributed to the smaller increase in takeover attempts. ${ }^{146}$

The second generation statutes had an insignificant effect on control premiums. The absence of higher control premiums when additional statutory delay is introduced was not predicted by either regulation proponents or opponents. Multiple bids normally result in a higher tender offer prices and thus in increased control premiums; the same result was expected when takeovers are aggregated. Our result is inconsistent with Professors Jarrell and Bradley's finding that regulations increase control premiums $^{147}$ but consistent with Professor Pound's conclusion that supermajority, staggered board, and authorized preferred antitakeover amendments deterred takeovers, made management more likely to succeed in resisting takeovers, but do not increase control premiums. There are several possible interpretations of the insignificant effect on control premiums. In anticipation of having to pay the first-step price to shareholders frozen out in the second step if the board or shareholders did not approve the transaction, bidders may have blended their first and second-step offer price, resulting in a lower initial offer price. Another explanation is that the effects of the second generation statutes were overshadowed by management-initiated defensive tactics such as poison pills, lock-ups, litigation, and antitakeover amendments employed by both second and nonsecond generation firms.

The second generation statutes increased the incidence of multiple bids but decreased the incidence of auctions relative to nonsecond generation

144. See supra notes $38-39$ and accompanying text.

145. See supra notes $44-48$ and accompanying text. As in any statistical study, there is the possibility that omitted variables may make the observed changes not solely attributable to takeover regulation.

146. However, without an econometric model predicting the number of takeover attempts that would occur in each state in the absence of second generation regulation, limited inferences may be drawn.

147. See supra text accompanying note 97. A survey of tender offers made during 1986 observed a declining trend in control premiums during recent years. Average control premiums in 1986 were $30.5 \%, 27.2 \%$ in $1985,31 \%$ in 1984 , and $39 \%$ in 1983 . This study based its calculation on control premiums on the target's market price two weeks before the offer rather than the forty-day period used by Jarrell and Bradley and in our study. Austin, Nigemi \& Bernard, Tender Offer Update: 1987, Mergers \& Acquisitions 49, 50 (July/Aug. 1987). 
states. This suggests that the delay and shareholder or board approval provisions of the statutes gave target management more leverage to both resist an offer and demand a higher price, while the requirements of the statutes deterred additional bidders from entering the contest.

Finally, the second generation statutes increased cumulative abnormal returns after takeover. The positive cumulative abnormal returns, however, were not as great in takeovers subject to the second generation statutes as they were in takeovers occurring in these same states when only the federal Williams Act applied. The second generation control group consisted of earlier tender offers. Therefore, changes in economic conditions not accounted for by the market model could be responsible for our results. When we compared the test group with the nonsecond generation control group, specifically matched to the test group to control for changes in economic conditions, the cumulative abnormal returns were significantly higher in the test group. This may reflect a market expectation of the decreased probability of freezeout at a lower value. To this extent, shareholders of target firms benefited. However, shareholders generally may have been made worse off by the statutes because they had less opportunity to participate in these profitable transactions and a decreased threat of takeovers monitors the market for corporate control less efficiently.

When these results are considered together, second generation statutes did not appear to maximize shareholder wealth. Under the narrow view, the statutes had no effect and under the broader view they had a negative effect. ${ }^{148}$ Under the narrow view of shareholder wealth, the statutes are evaluated for their effect on the amount received by target shareholders in the tender offers. Because the statutes had an insignificant effect on control premiums, they failed to maximize target shareholder wealth. According to an indication of more general shareholder wealth recognized by both sides of the debate-the expected takeover premium, ${ }^{149}$ the wealth of shareholders of firms incorporated in states with second generation statutes was decreased by second generation statutes. The expected takeover premium is the product of the average control premium and the likelihood that a takeover will occur. Since there was an insignificant effect on control premiums under the statutes and the likelihood of a takeover was less than in states without second generation statutes, shareholders were relatively worse off under the second generation statutes. The second generation firm shareholders had a relatively smaller chance of receiving the same control premium as nonsecond generation firm shareholders. Thus, our results of the second generation statutes' direct effects confirm the

148. See supra note 3.

149. See supra note 39 . 
market's negative reaction to their enactment as being detrimental to shareholders.

Shareholders generally were made worse off by the decreased threat of takeovers. Takeovers police the market for corporate control. Thus, fewer takeover attempts and a smaller percentage of successful takeovers increased agency costs because takeovers were less effective as a constraint on inefficient management. ${ }^{100}$ Moreover, to the extent that takeovers were deterred by the statutes, fewer market inefficiencies were corrected through the takeover process.

\section{CoNCLUSION}

This Note provides some empirical evidence concerning the effects of second generation statutes on shareholder wealth. The evidence indicates that the statutes deterred takeover attempts, reduced the likelihood of a successful acquisition, increased the incidence of multiple bids, decreased auctions, and increased positive abnormal returns, but had an insignificant effect on the control premiums received by target shareholders. Although shareholders were generally harmed financially by the statutes, the data could not provide definitive answers to some of the issues raised by tender offer regulation. However, our study provides evidence for legislators to consider before enacting these types of statutes for the purpose of promoting shareholder wealth. 
